\title{
DIGESTER GAS - FUEL CELL - PROJECT
}

\section{Final Report}

for the

U.S. DEPARTMENT OF ENERGY

Time of Report March 2000 - April 2001

Published in March 2002

Presented by plant operator of

GEW Köln AG

Parkgürtel 24

50823 Köln

Area Energy Economy

Dr.-Eng. Dirk Adolph

Dipl.-Eng. Thomas Saure

DOE Instrument NO.: DE-FG26-00NT41045

Gas-, Electricity- and Waterworks

GEW Koln AG

Parkgurtel 24

50823 Cologne

GERMANY 


\section{DISCLAIMER}

This report was prepared as an account of work sponsored by an agency of the United States Government. Neither the United States Government nor any agency thereof, nor any of their employees, makes any warranty, express or implied, or assumes any legal liability or responsibility for the accuracy, completeness or usefulness of any information, apparatus, product, or process disclosed, or represents that its use would not infringe privately owned rights. Reference herein to any specific commercial product, process, or service by trade name, trademark, manufacturer, or otherwise does not necessarily constitute or imply its endorsement, recommendation, or favouring by the United States Government or any agency thereof. The views and opinions of authors expressed herein do not necessarily state or reflect those of the United States

Government or any agency thereof. 


\begin{abstract}
GEW has been operating the first fuel cell in Europe producing heat and electricity from digester gas in an environmentally friendly way. The first 9,000 hours in operation were successfully concluded in August 2001.

The fuel cell powered by digester gas was one of the 25 registered "Worldwide projects" which NRW presented at the EXPO 2000. In addition to this, it is a key project of the NRW State Initiative on Future Energies.

All of the activities planned for the first year of operation were successfully completed: installing and putting the plant into operation, the transition to permanent operation as well as extended monitoring till May 2001.
\end{abstract}


TABLE OF CONTENTS

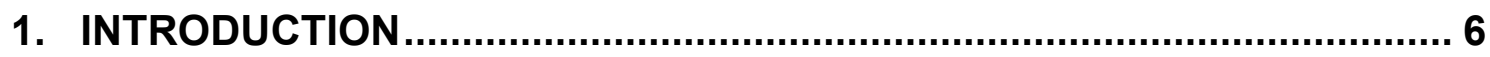

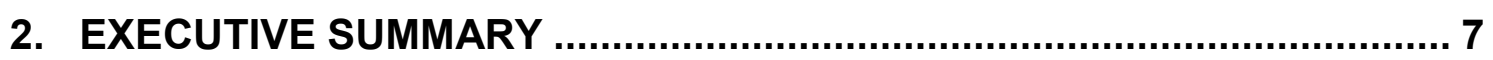

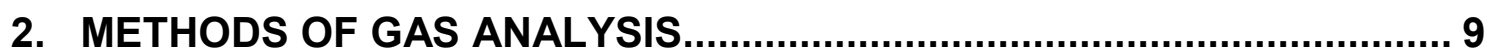

3. SEWAGE PLANT KOELN-RODENKIRCHEN ..................................... 10

4. FUEL CELLS AND PERIPHERY ....................................................... 12

5. RESULTS AND DISCUSSIONS OF THE OPERATING DATA ................. 20

5.1. Digester gas cleaning ……..................................................................20

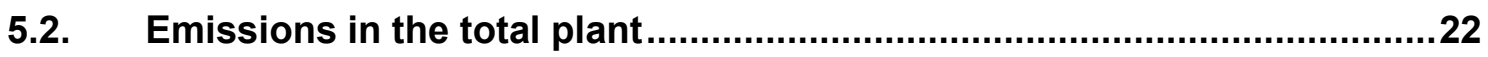

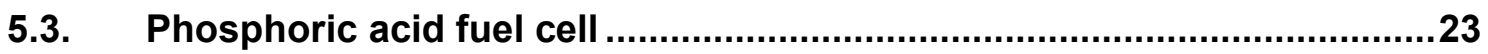

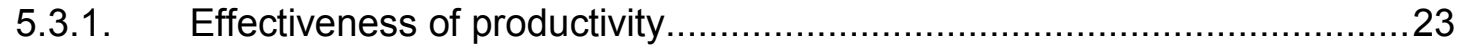

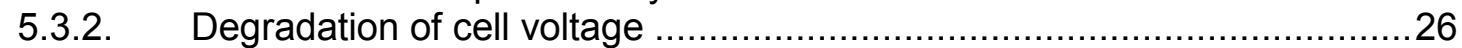

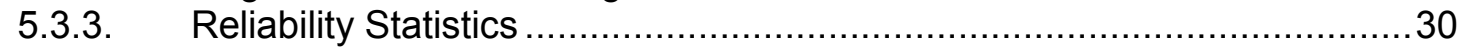

5.3.4. Thermal Output................................................................................

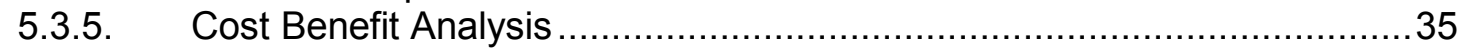

6. CONCLUSION

APPENDIX: $\quad$ FUELL CELL FOTO DOCUMENTATION 


\section{TABLE OF DIAGRAMS AND TABLES}

DIAGRAM 1 AERIAL PHOTO OF COLOGNE-RODENKIRCHEN SEWAGE PLANT .................10

DIAGRAM 2: MECHANICAL CONSTRUCTION OF THE FUEL CELL PLANT ..........................12

DIAGRAM 3 DIGESTER GAS TANK (FUEL CELLS IN FRONT) ….................................. 13

DIAGRAM 4 PROCESS PLAN OF GAS CLEANING DEVICE WITH HEAT EXCHANGER ............ 14

DIAGRAM 5 PROCESS PLAN OF FUEL CELL DEVICE ......................................... 19

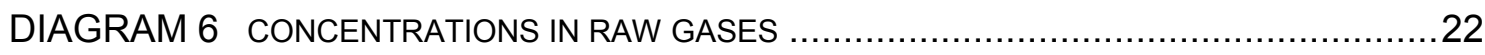

DIAGRAM 7 COMPARISON BETWEEN EFFICIENCY AND CAPACITY ..................................25

DIAGRAM 8 DEPENDANCY OF CELL VOLTAGE ON HOURS WORKED ..............................29

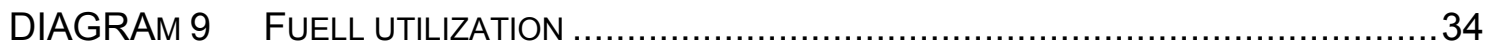

DIAGRAM 10 ELECTRIC POWER AND THE SPECIFIC THERMAL OUTPUT ..........................35

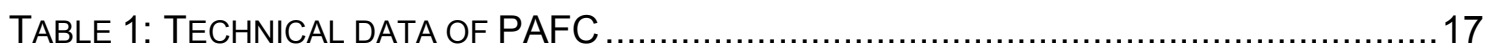

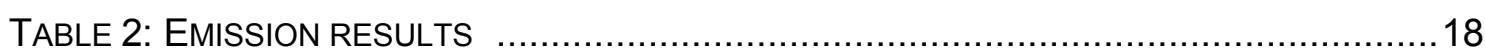

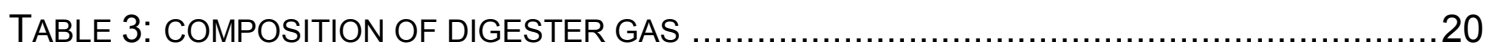

TABLE 4: HARMFUL SUBSTANCE RESULTS IN DIGESTER GAS ANALYSIS ..........................21

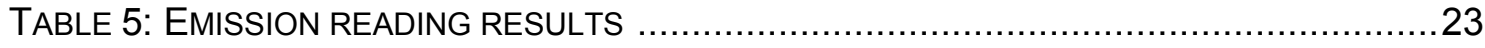

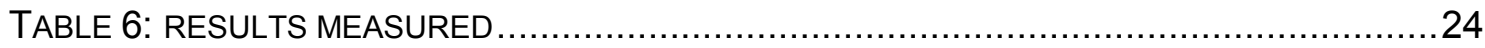

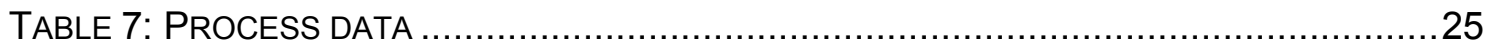

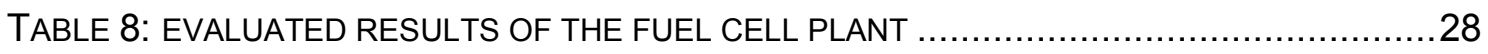

TABLE 9: PERIOdS Of OPERATION AND STOPPAGE OF THER FUELL CELL PLANT .................30

TABLE 10: ADDED LIST FOR EXPLAINING THER RELIABILTY STATISTICS ............................301

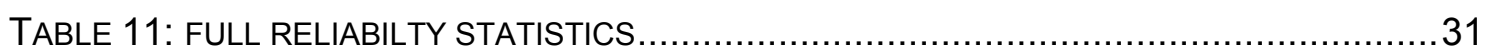

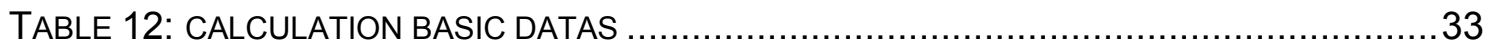

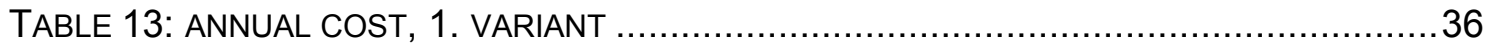

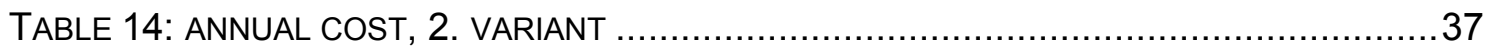

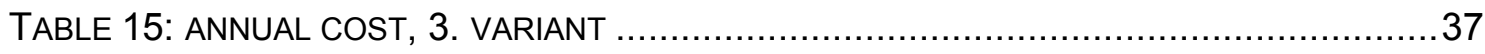

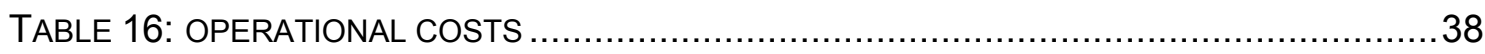

TABLE 17: COMPARISATION OF VARIANTS AND SPECIFIC LOSSES................................ 38

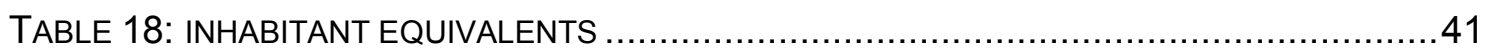




\section{INTRODUCTION}

GEW Köln AG places great importance on an ecologically harmless supply of energy. GEW is a customer-orientated company which has contributed to the development and support of advanced energy technology for many years. As a result, the consolidation of ecologically harmless natural gas-and district heating supply, for example, has led to a considerable reduction in carbon dioxide emission. The company's activities are rounded off with demonstration equipment used for wind and solar energy as well as relevant aid programmes. In accordance with this conservation strategy, GEW is involved in a project for innovative fuel cell technology which has a promising future.

Fuel cells are a part of the most promising future technology in the field of energy. They can make a crucial contribution to the environmental effects of future energy supplies. Compared with conventional heat-power-machines, electrochemical electricity and heat generation using fuel cells shows the following considerable advantages:

- electrical effectiveness is high, especially in the area of part load.

- reaction to rules in all areas of performance is very good.

- production of harmful substances is almost unnoticeable.

- noise levels are minimum.

Hydrogen is the fuel for the electrochemical conversion. This is, of course, available exclusively in a chemically bound form in nature. In the Cologne-Rodenkirchen sewage plant, we first obtain hydrogen from digester gas. Electricity generation from digester gas into fuel cells is ecologically harmless - neither nitrogen oxides nor carbon monoxide nor sulphur oxides are produced as they are released in the burning of digester gas. Moreover, using this renewable form of energy spares the resources of fossil energy forms and reduces hothouse gas emission. As a result, annual carbon dioxide is reduced by as much as 1,000 tons. 


\section{EXECUTIVE SUMMARY}

Digester gas is produced from the direct conversion of biomas and is a renewable form of energy, as a non-fossil fuel. Therefore, the conversion of energy from digester gas into fuel cells for electricity and heat does not result in additional hothouse gas emission.

The Cologne-Rodenkirchen sewage plant used a phosphoric acid fuel cell, model PC25C, from the American company International Fuel Cells (previously ONSI) for the energetic use of digester gas. The plant has an electrical capacity of $200 \mathrm{~kW}$ and a thermal capacity of $205 \mathrm{~kW}$. Compared with the standard plant operating on natural gas, the manufacturer has changed, among other things, the cross-sections to the reformer and cell stack.

\section{Research contribution of new gas processing}

Compared with natural gas, the chemical composition of digester gas changes constantly with the composition of sludge. Special demands are made on gas cleaning. Sulphur, halogen and organic silicon (siloxans) combinations found in gas can hinder the catalytic and chemical process in the fuel cell plant even with a low concentration. In cooperation with an engineering office, an innovative, process engineered gas cleaning device was developed to guarantee the necessary separation efficiency with economically justifiable expenditure.

The cleaning device consists of a two-stage basic cleaning unit and then an adsorption phase with a particle filter is switched on. Gas is pre-cooled and then frozen in the basic unit. The most important part of this phase is the separation of the organic silicon and the virtual drying of the gas. Halogen and sulphur combinations are removed using activated carbon. A filter is then switched on to remove particles larger than $0,5 \mu \mathrm{m}$. Building the device, guarantees that the necessary process engineering pollution limits are adhered to. The cleaning device starts operation at the low level of $3.5 \mathrm{~kW}$.

Research contribution of digester gas use in a fuel cell plant and the complete use of waste heat

The fuel cell plant PC25C consists mainly of gas processing (reformer/converter), the fuel cell stack and the DC-AC converter. Gas processing changes the clean digester gas to gas with a high content of hydrogen. This takes place in a steam reformer at approx. $900^{\circ} \mathrm{C}$ on a copper catalyst and then in a converter on a copper catalyst at approx. $300^{\circ} \mathrm{C}$.

The gas used in the electrochemical process in the fuel cell stack contains more than $50 \%$ hydrogen. The chemical energy in this gas is changed to electrical energy at $200^{\circ} \mathrm{C}$ in the fuel cell. All year round, the heat released is transferred in a heat exchanger for sludge to bio-sludge and heats the digester gas tank.

The direct current generated converts the DC-AC converter to an alternating current with a voltage of 400 Volt and installs it into the local low voltage mains. The operation of the plant is dependent on the amount of digester gas accumulated. The electricity produced covers approximately $50 \%$ of that required by the sewage plant. This provides the supply for 500 accommodation units. 


\section{Annual figures}

Measurements of raw and refined gas help document the quality of the digester gas and the degree of separation in gas processing. The measurement programme contains a virtually continuous admission and analysis of the gas components methane, carbon dioxide, hydrogen sulphide and oxygen as they enter the fuel cell. Furthermore, a discontinuous measurement of harmless substance components (trace gases) is carried out before and after the gas cleaning process.

Until now measurements have confirmed the performance expected of digester gas cleaning designed for a maximum gas throughput of $110 \mathrm{~m}^{3} / \mathrm{h}$. As a result, the sulphur content, for example, could be reduced to $40 \mathrm{mg} / \mathrm{m}^{3}$ in raw gas and to as low as $1 \mathrm{mg} / \mathrm{m}^{3}$ in refined gas. The levels of chlorine and fluorine(halogen) found in refined gas are as low as $1 \mathrm{mg} / \mathrm{m}^{3}$. Organic silicon was no longer present in refined gas.

Such positive annual figures from the demonstration plant prove that, with an efficient gas cleaning device, it is possible to use biogenetic gases in fuel cells. The first trial run of fuel cells took place on 08.03.2000. On 03.14. full electrical efficiency was proved for the first time at $200 \mathrm{~kW}$ while putting it into operation. Since 06.01.2000, the complete plant has shown a $94.8 \%$ availability. There has only been one fault in the fuel cell plant since the level of full operation was reached. This was caused by a leak in the cathode air supply All other cases of switching off the entire plant were due to the fuel cell launching phase or to faults in conventional plant components.

The plant operates at a high level of electrical efficiency which is slightly reduced to $38.3 \%$ by the operation of the gas cleaning device (own use) and the refined gas composition. The loss of efficiency under part load conditions (by $50 \%$ ) is extremely low. Regarding harmful gases, the plant operates, as expected, almost emission-free. 


\section{METHODS OF GAS ANALYSIS}

Methods of setting the parameter of digester gas are based on standard laboratory instructions and follow the prevailing specifications of DIN- (Deutsches Institut für Normung e.V.) and VDI- (Verein Deutscher Ingenieure).

The following methods were used:

- Main component $\left(\mathrm{O}_{2}, \mathrm{~N}_{2} ; \mathrm{CH}_{4} ; \mathrm{CO}_{2}\right):$ GC/WLD

- Halogen Hydrocarbon GC/MS \& GC/ECD

- Aromatic Hydrocarbon GC/MS \& GC/ECD

- $\mathrm{H}_{2} \mathrm{~S}$ : electrochemical

- Organic Silicon: GC/MS

$\begin{array}{lll}\text { GC } & =\text { Gas chromatography } \\ W L D= & \text { heat conductivity detector } \\ E C D= & \text { Electron Capture Detector } \\ M S= & \text { Mass spectrometric }\end{array}$




\section{SEWAGE PLANT KOELN-RODENKIRCHEN}

The city of Cologne has four sewage plants all together. These plants are responsible for the sewage of approximately one million inhabitants as well as local industrial and commercial waste.

The Cologne-Rodenkirchen sewage plant went into operation in 1956 with the construction of the sewage system and was expanded in 1972-1995 due to a biological purification phase. The sewage of approximately 61,000 inhabitants is purified in the plant. The purification of commercial and industrial waste amounts to a sewage load of a further 27,000 inhabitant equivalents[1]. Therefore, sewage freight corresponds to approximately 88,000 inhabitant equivalents.

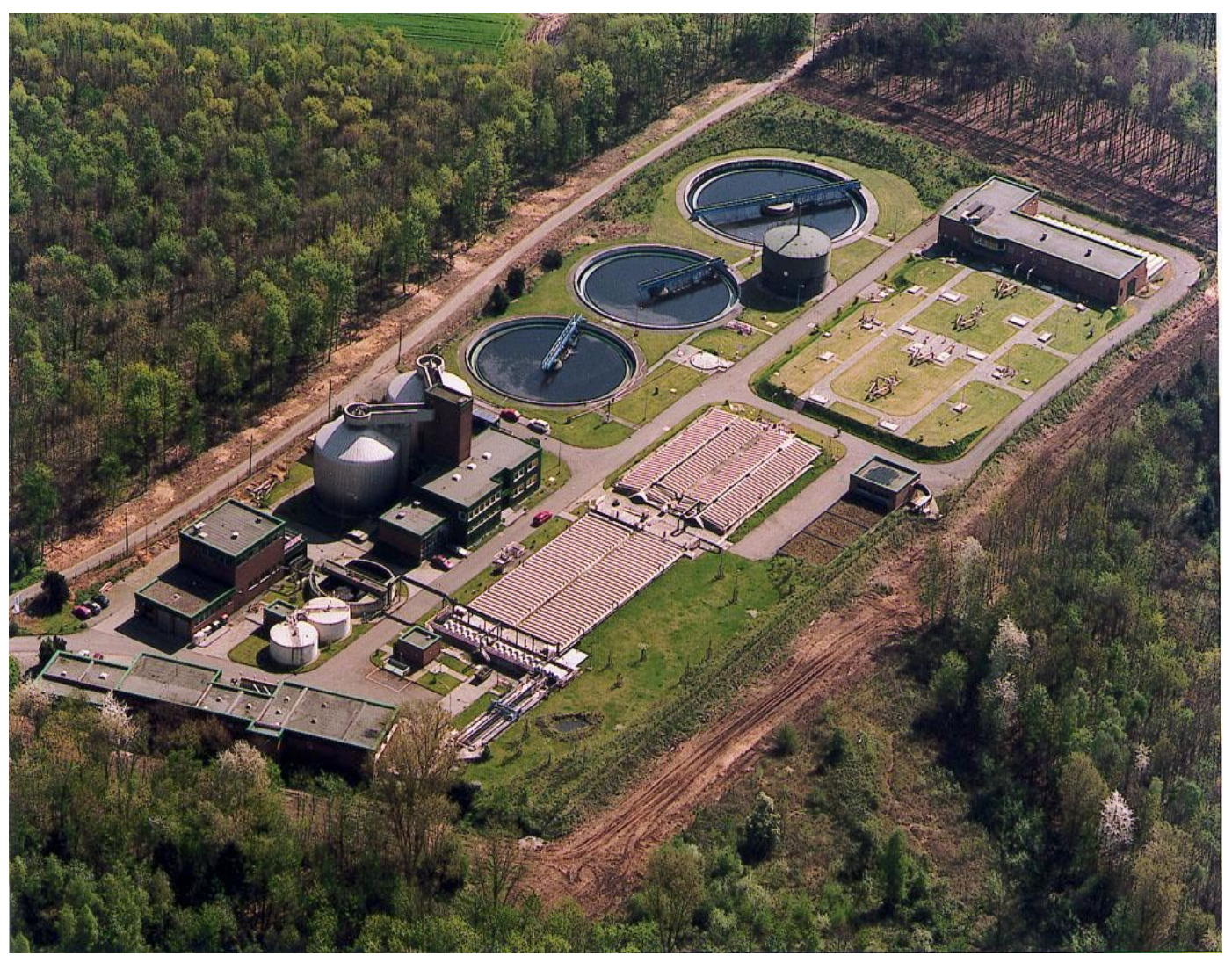

Diagram1: aerial photo of Cologne-Rodenkirchen sewage plant [2] 
Process engineering of the sewage plant is directly connected to the production of digester gas. Within the framework of the purification phase, the mechanical preliminary settling and the sewage from households and industrial companies is pre-purified with the help of a sieve grill. Accumulated coarse substances like paper, wood and remnants are collected in containers and disposed of. The sewage finally ends up in a follow-on ventilated sandpit for the separation of mineral substances. In the next phase, the sewage is spread out in a clarification basin which is covered due to the stench. Light floating substances with little density are separated here.

In addition to dissolved and non-dissolved biologically decomposing substances, sewage consists of a multitude of micro-organisms which ensure the decomposition of organic freight in a natural way. Maximum substance turnover is reached in the activating basin ( $2^{\text {nd }}$ cleaning phase) by adjusting ideal living conditions (extra oxygen, intermixed) from the bacteria derived from the decomposing procedure. By zoning the basin in the ventilated (aerobe) and non-ventilated (anaerobe) areas, the decomposition of dissolved nitrogen-, carbon- and combinations can be continued, using metal salt. phosphate combinations. In a $3^{\text {rd }}$ cleaning phase, an almost complete separation of existing phosphate is carried out.

In the post-clarification basin, bio-sludge is separated from water. After being partly dehydrated, part of the bio-sludge is put back into the fermentation power as bio-mass which is constantly growing due to the steady cell increase of the micro-organisms. Further decomposition of organic substances takes place with the help of methanogenic bacteria, in a period of 26 days non-ventilated (anaerobe) and at a constant temperature of $39^{\circ} \mathrm{C}$ (mesophyll). One of the main products of rotting is digester gas which is a combination of mainly methane $\left(\mathrm{CH}_{4}\right)$ and carbon dioxide $\left(\mathrm{CO}_{2}\right)$ at a ratio of $63: 37$. 


\section{FUEL CELLS AND PERIPHERY}

\section{Plant Concept}

In order to obtain complete energetic use of digester gas from the rotting process, a gas motor decentralized combined power plant is typically used. A phosphoric acid fuel cell has been used for the first time in Europe instead of conventional internal combustion engines.

Diagram 2 mechanically shows the various steps of procedures in the plant.

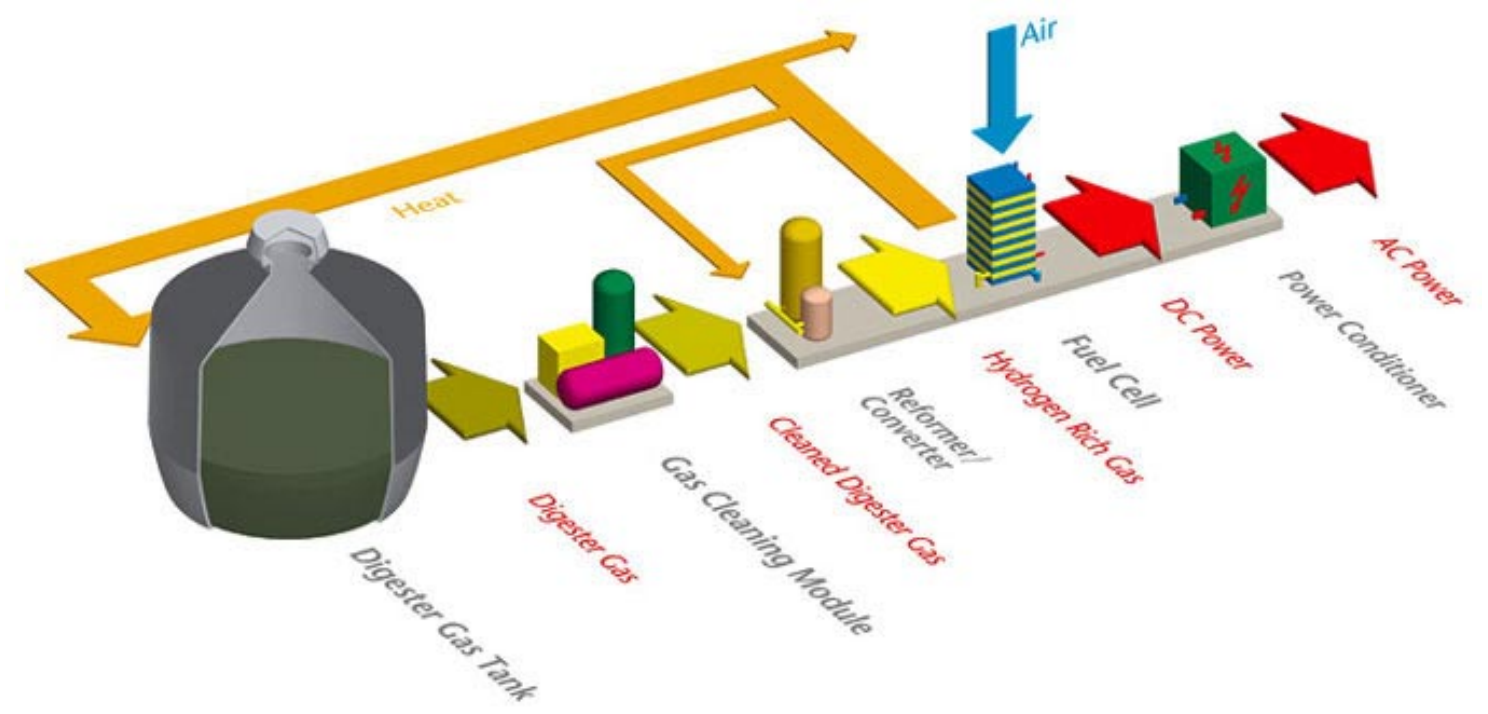

Diagram 2: mechanical construction of the fuel cell plant [5]

Procedural steps:

1.) Digester gas tank $\rightarrow$ supplies the fuel cells with methylated gas

2.) Digester gas cleaning $\rightarrow$ Purification of digester gas

3.) Reformer/Converter $\rightarrow$ Conversion to hydrogen rich gas

4.) Fuel cell $\rightarrow$ Generation of heat and electricity

5.) DC/AC Converter $\rightarrow$ Voltage change

Waste heat generated from the fuel cell can be coupled back to previous plant parts, as shown in diagram 2. This results in an improvement in the overall efficiency of the plant. It is of crucial importance to the plant as a whole to save the resources of fossil energy and reduce annual carbon dioxide to 1000 tons. 


\section{Digester gas tank}

The circulation, loading, vaccination and settlement of sludge are important parameters for the operation of the digester gas tank.

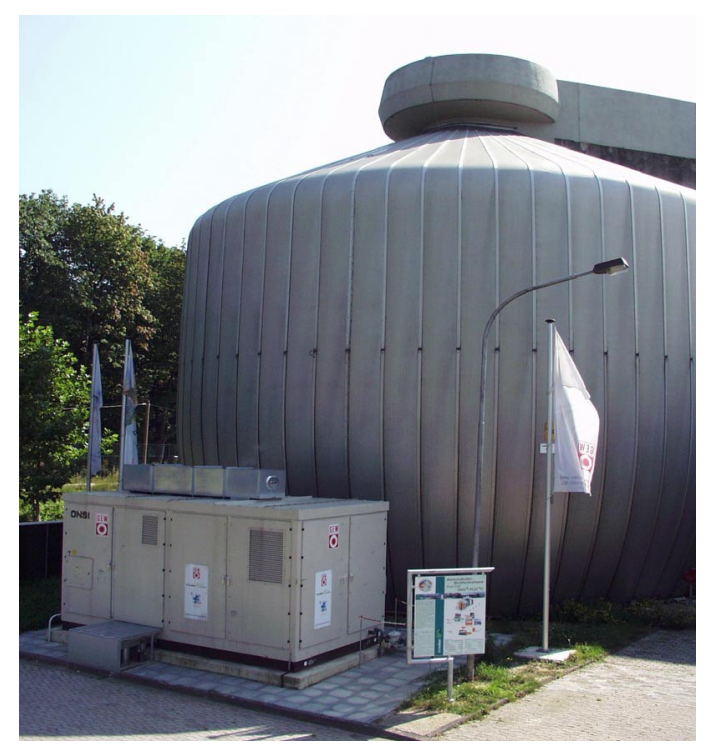

Diagram 3: Digester gas tank (fuel cell in front) [9]

\section{Digester gas cleaning}

The digester gas produced is brought to the next step in the cleaning process. Digester gas cleaning is an elementary and absolutely necessary part of the plant concept. Even the slightest amounts of undesirable organic combinations, like silicon compound, sulphur and halogen, can considerably hinder the efficiency of the fuel cell catalyst and cause its destruction. The cleaning device consists of a 2-step basic cleaning unit as well as a follow-on adsorption level with a particle filter.

The following diagram shows the journey of raw gas through the cleaning device. 


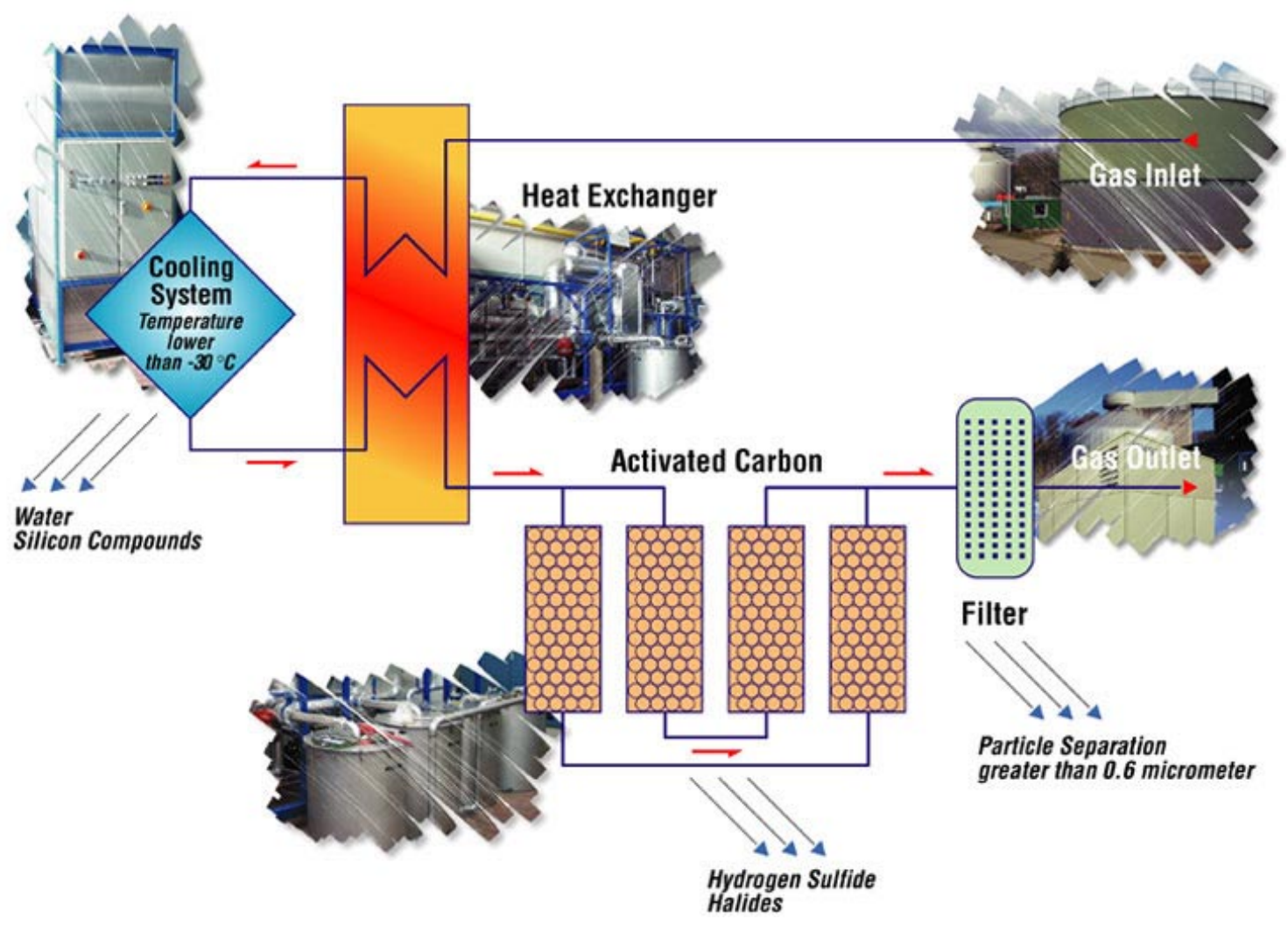

Diagram 4: Process plan of gas cleaning device with heat exchanger

The refrigeration technical device consists of a 2-step basic cleaning unit. The processed gas is chilled at a temperature of $-30^{\circ} \mathrm{C}$. Condensation and ice formation occur due to the moisture contained in the device. Ice absorbs organic silicon which is damaging to the device.

Siloxans are organic silicon compounds which crystallize from the formation of $\mathrm{SiO}_{2}$ (quartz) in the fuel area of gas engines and can cause destruction. As a precaution, gaseous organic silicon was removed as there was not sufficient experience in dealing with it within the electrochemical processes at the time of constructing the device.

Periodic thawing phases are necessary to filter out harmful substances and the water load of ice The system has two parallel refrigeration sections which can be thawed reciprocally. The resulting amount of condensation depends on the saturation temperature, outdoor temperature and the location of the device.

The resulting warm gas is pre-cooled when returned with cold refined gas via a recuperator. The necessary temperature level for cold refined gas can be raised at the same time using a special gas guide. The advantage of this technology is based on a reduction in the energy requirement for the whole cleaning plant by almost $45 \%$. 
A refined gas returning device is installed to prevent ice formation in the area of energy recycling. This can be controlled as required with a built-in compressor. Taking these measures into account, a continuous cleaning operation of the refrigeration device is carried out. Thermal energy, removed from the digester gas during the refrigeration process, can be drawn off to the surrounding area via a used water cooler. The cleaning device's energy requirement is particularly low with an efficiency level of $3.5 \mathrm{~kW}$. Due to economic reasons, the manufacturer has resorted to a standardized device which corresponds with the general regulations of technology [3].

The activated carbon filter phase (adsorption phase) has two parallel filter sections where halogen and sulphur compositions can be substantially removed using activated carbon.

The basic effect of adsorption is based on the surface area effect. Activated carbon has a very large inner surface and so harmful substances can be absorbed in the microscopically small pores. To ensure the most effective use of activated carbon, each filter section has two filter units with a series of switches. Maximum loading capacity is achieved in each filter using the switching.

In addition, continuous operation is guaranteed even when the activated carbon has to be exchanged. It is not possible to perform with full cleaning efficiency shortly after the filter has been changed. At the end of the process, there is an additional particle filter which removes all of the particles larger than 0.5 micrometers from the gas [3].

\section{Reformer/Converter}

Digester gas is mixed with overheated steam from reformer reaction and put into the reformer. Digester gas is changed to oxygen-and carbon monoxide gas in a copper catalyst at $800^{\circ} \mathrm{C}$. The reaction equation is:

$\mathrm{CH}_{4}+\mathrm{H}_{2} \mathrm{O} \rightarrow \mathrm{CO}+3 \mathrm{H}_{2} \quad(\Delta \mathrm{H}=207 \mathrm{KJ} / \mathrm{mol})$

The reformer reaction runs endothermal. The heat required is provided by burning fuel gases (approx.15\% of fuel gas) which were not converted in the fuel cell reaction.

However, the concentration of carbon monoxide is too high to be used as fuel gas for the fuel cell. Carbon monoxide would cover the platinum catalyst and then reduce the efficiency of the fuel cell and finally cause its destruction. 
For this reason, the gases are cooled to almost $200^{\circ} \mathrm{C}$ after the reformer process. The cooled gas is then put into a carbon monoxide converter. Any steam still present in the gas is catalytically changed here with carbon monoxide to oxygen and carbon dioxide. This reaction runs exothermal:

$\mathrm{CO}+\mathrm{H}_{2} \mathrm{O} \rightarrow \mathrm{CO}_{2}+\mathrm{H}_{2} \quad(\Delta \mathrm{H}=-41 \mathrm{KJ} / \mathrm{mol})$

The amount of carbon monoxide is so low after this phase that any damage to the fuel cell can be ruled out. The amount of oxygen is increased to $50 \%$ before entering the fuel cell. The rest of the cleaned and prepared process gases are made up of steam, nitrogen, carbon dioxide and traces of methane and carbon monoxide [4].

\section{Phosphoric acid fuel cell (PAFC-Phosphoric Acid Fuel Cell)}

The phosphoric acid fuel cell is operated at a medium temperature of approx. $200^{\circ} \mathrm{C}$. The cell runs on concentrated, almost water-free phosphoric acid $\left(\mathrm{H}_{3} \mathrm{PO}_{4}\right)$ which serves as an electrolyte. Using an acid as an electrolyte makes it possible to use fuel gas of low purity as a source of energy. Therefore, fuel gas with $\mathrm{CO}_{2}$-content can be used, for example, because the gas does not react with the acid. For this reason, PAFC is also suitable for generating electricity from hydrocarbon because the $\mathrm{CO}_{2}$ accumulated in the reformer process does not have to be removed.

Tolerance of carbon monoxide $(\mathrm{CO})$ is increased by the high operating temperature. The electrodes consist of carbon substances combined with plastic which are covered with catalytic-working precious metal particles. Phosphoric acid is present as a gel set in a matrix. The capacity of most of the PC25C models in operation lies between 50 $200 \mathrm{~kW}$ with a density of $350 \mathrm{~mA} / \mathrm{cm}^{2}$. The cell voltage generated is 0.6 Volt [5].

\section{Plant configuration}

The fuel cell module basically consists of two different plant parts. On the one hand, it deals with the fuel cell unit including gas processing and, on the other hand, with the refrigeration module which guides surplus heat to the surrounding air. The refrigeration module consists of a table cooler with three axial ventilators. Both units are suitable for assembly indoors or outdoors.

A capacity statement of $200 \mathrm{~kW}$ and $205 \mathrm{~kW}$ refers to net-capacity. All of the energy used for the fuel cell and its periphery has already been deducted from all capacity statements. The plant comprises of additional equipment like the wiring of the electrical mains, pipes for heat supply as well as a pipe connection between the fuel cell and the refrigeration module. 
The electrical efficiency of this class is almost at a level where advanced gas engines are established. However the overall effect of electricity and heat use is considerably higher and can achieve results of up to $85-90 \%$. There is also the advantage of a constantly high effectiveness with a part-load operation of up to $50 \%$.

Some of the plant's technical data is shown in table 1 (all data refers to the use of digester gas as fuel gas):

\begin{tabular}{|ll|}
\hline \multicolumn{2}{|c|}{ Technical data of the fuel cell plant } \\
\hline Primary energy & Digester gas \\
\hline Electrical power & 200 Kilowatt \\
\hline Electrical standard-effect & 40 Percent \\
\hline Thermal power & 205 Kilowatt \\
\hline Thermal standard effect & 45 Percent \\
\hline Forerun temperature & $60^{\circ} \mathrm{C}$ \\
\hline Counter current temperature & $40^{\circ} \mathrm{C}$ \\
\hline measurements $(\mathrm{L} / \mathrm{B} / \mathrm{H})$ & $5.5 \mathrm{~m} / 3 \mathrm{~m} / 3 \mathrm{~m}$ \\
\hline weight & Approx 18 tons \\
\hline
\end{tabular}

Table 1: technical data of PAFC

The phosphoric acid fuel cell can generate heat at a medium temperature level of up to $80^{\circ} \mathrm{C}$. It is possible to adjust the plant to various temperature levels. The level of heating power obtained depends greatly on the forerun and counter-current temperature of the prevailing heating mains.

The forerun and counter-current temperature must be set as low as possible in order to obtain a high thermal effect. Heat is coupled via a cycle filled with a water/glycol mixture from the fuel cell and transferred to the heat mains via a plate heat exchanger.

The fuel cell stack itself does not produce any emission of noise. Only the periphery of the process make some sound, like the various ventilators for the removal of cold air. The maximum level of sound, caused by the ventilation of the system, was recorded at a distance of 10 meters from the plant and registered $62 \mathrm{~dB}(\mathrm{~A})$.

The chemical conversion of energy in the cell stack of PC25C is practically carried out emission-free and, many times over, surpasses the limits stipulated by TA-Luft (TA-Luft 
$=$ Administrative regulations „technical instructions for air“). Emission results measured are presented as an example in table 2 and refer to natural gas as the energy supplier.

\begin{tabular}{|l|l|l|l|}
\hline $\begin{array}{l}\text { Harmful } \\
\text { substances }\end{array}$ & \multicolumn{2}{|l|}{ Emission readings } & TA-Luft 1986 \\
\hline & {$[\mathrm{g} / \mathrm{kWh}]$} & {$\left[\mathrm{mg} / \mathrm{m}^{3} \mathrm{i.N}\right]$} & {$\left[\mathrm{mg}^{2} \mathrm{~m}_{\mathrm{i} . \mathrm{N} .}^{3}\right]$} \\
\hline $\mathrm{NO}_{\mathrm{x}}$ & $0.06 \ldots 0.03$ & $7 \ldots \ldots 14$ & 500 \\
\hline $\mathrm{CO}$ & $0.02 \ldots 0.05$ & $7 \ldots \ldots .22$ & 650 \\
\hline $\mathrm{SO}_{\mathrm{x}}$ & None & none & --- \\
\hline $\mathrm{C}_{\mathrm{x}} \mathrm{H}_{\mathrm{y}}$ & $0.03 \ldots 0.07$ & $12 \ldots .17$ & 150 \\
\hline dust & None & none & --- \\
\hline
\end{tabular}

Table 2: Emission readings [6]

Water is a left-over product of the electro-chemical conversion and must be removed from the fuel cell stack. It is distilled from the waste gas and returned to the reformer cycle.

The amount of condensation removed depends on the temperature of the surrounding air. However, the plant can still be operated at an outdoor temperature of over $40^{\circ}$ with the help of a separate water tank which is fed by the city's drinking water system. If the water supply is interrupted, there is an automatic reduction in the productivity of the plant in order to reduce the water consumption in the reformer. This reduction in productivity will be maintained until water is supplied externally.

The fuel cell generates a direct current which must be converted in a DC/AC converter as the public electricity supply system is operated on an alternating current. The electricity supply system has a voltage of 400 Volt with a mains frequency of 50 hertz. The plant can be operated by electrical power (200 kW) with an adjustable productivity of between 0.85 productive and 0.85 inductive. The plant operates on a parallel power supply system.

Construction of the fuel cell complies with standards of explosion and fire protection. The container is continuously subject to compulsory ventilation so that flammable substances would not develop in the event of a gas leak.

Operating conditions of the plant are continuously supervised and evaluated for security reasons by a steering mechanism. The fuel cell is equipped with a modem to guar- 
antee a remote monitoring of the plant [6]. The plant automatically stops the supply when there is a fault in the power supply system. Diagram 5 shows the processing plan of the phosphoric acid fuel cell device and the preceding gas processing.

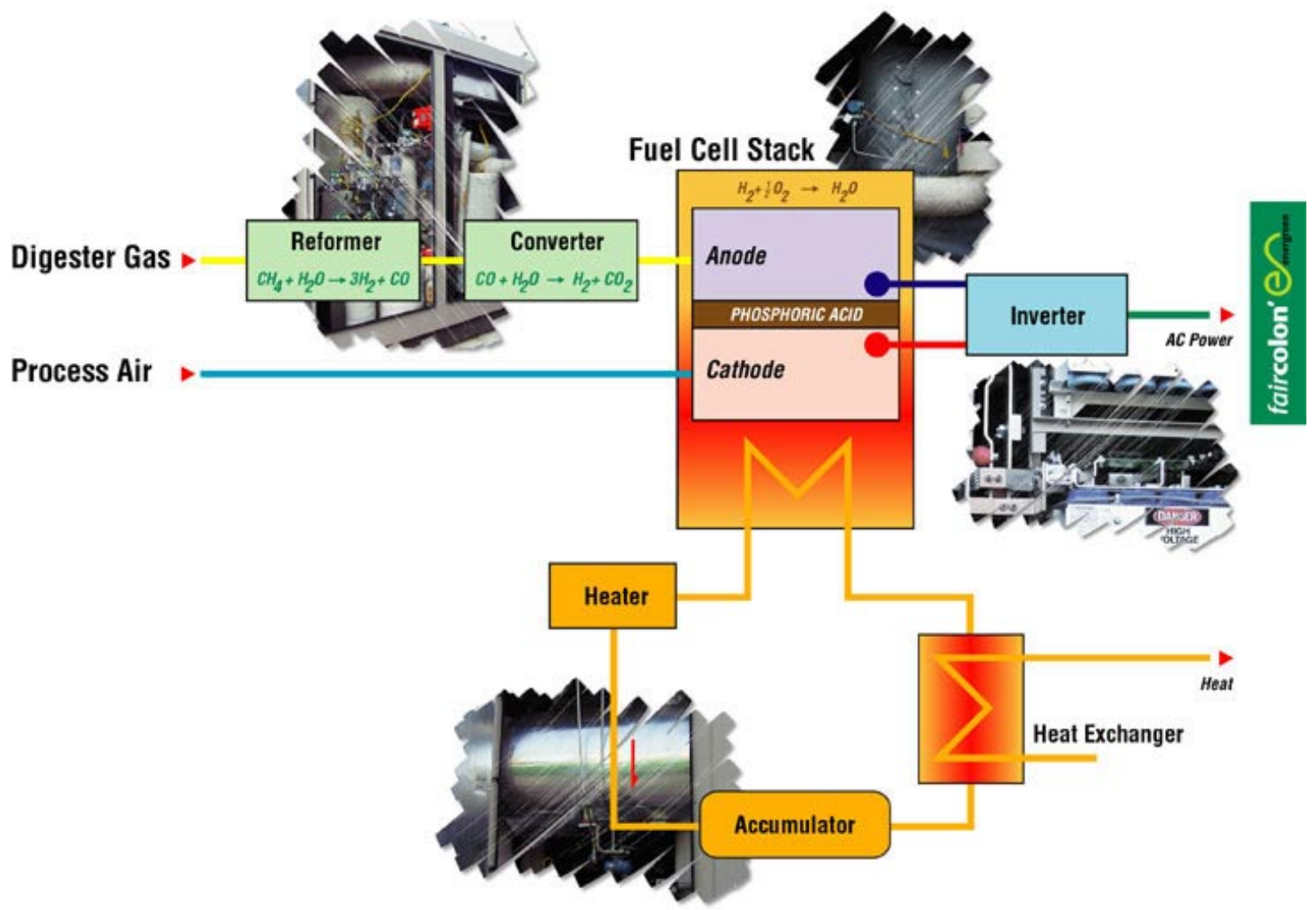

Diagram 5: Processing plan of the fuel cell device 


\section{RESULTS AND DISCUSSIONS OF THE OPERATING DATA}

Readings are constantly being recorded and documented in the Cologne-Rodenkirchen sewage plant to guarantee the faultless operation of the phosphoric acid fuel cell (PC25C) and the accompanying gas cleaning. Data can be used to diagnose faults as well as assess operations. Operating data recorded is then evaluated and assessed.

\subsection{Digester gas cleaning}

Gas accumulated in the fermentation power of the sewage plant is in a filthy condition and called raw gas. It is completely unsuitable to be used by the fuel cell. in this condition. Raw gas must first of all be prepared before it can be used as fuel gas. The following parameters, taken from digester gas analysis, are the foundation for the development of the gas cleaning plant:

\section{Composition of digester gas}

\begin{tabular}{|ll|}
\hline$-\mathrm{CH}_{4}:$ & $>55 \mathrm{Vol} .-\%$ \\
$-\mathrm{CO}_{2}:$ & $<45 \mathrm{Vol} .-\%$ \\
$-\mathrm{N}_{2}:$ & $<2 \mathrm{Vol} .-\%$ \\
$-\mathrm{O}_{2}:$ & $<0.3 \mathrm{Vol} .-\%$ \\
-organic silicon content & up to $5.110 \mu \mathrm{g}$ \\
-total sulphur & $<6 \mathrm{mg} / \mathrm{m}^{3}$ \\
-halogen & $<10 \mathrm{ppmv}$ \\
-ammonia & $<0.5 \mathrm{ppmv}$ \\
-moisture & saturated \\
-calorific value: & $21 \mathrm{MJ} / \mathrm{Nm}^{3}$ \\
\hline
\end{tabular}

Table 3: composition of digester gas [3]

In order to check that the gas cleaning plant was operating faultlessly, readings were taken of raw gas before beginning the cleaning phase and on coming out as refined gas. The following results could be ascertained from laboratory analysis: 


\begin{tabular}{|l|c|c|c|c|}
\hline \multicolumn{5}{|c|}{ Digester gas analysis of the Cologne-Rodenkirchen sewage plant } \\
\hline Date of sampling & 03.23 .00 & 09.26 .00 & 11.14 .00 & 12.12 .00 \\
\hline Raw gas & 3.7 & 2.4 & 2.74 & 3.06 \\
\hline Total siloxans & 1.4 & 0.91 & 1.04 & 1.16 \\
\hline Total organic silicon & 33 & 1.4 & 40 & $<1.0$ \\
\hline Total sulphur & $<1.0$ & $<1.0$ & $<1.0$ & $<1.0$ \\
\hline Total fluorine & $<1.0$ & $<1.0$ & $<1.0$ & $<1.0$ \\
\hline Total chlorine & 35 & 1.5 & 43 & $<1.0$ \\
\hline Hydrogen sulphide & \multicolumn{5}{|l|}{} & \\
\hline Refined gas & not & not & 0.18 & not \\
\hline Total siloxans & detectable & detectable & & Detectable \\
\hline Organic silicon & not & not & 0.07 & not \\
& detectable & detectabler & & Detectable \\
\hline Total sulphur & $<1.0$ & $<1.0$ & $<1.0$ & $<1.0$ \\
\hline Total fluorine & $<1.0$ & $<1.0$ & $<1.0$ & $<1.0$ \\
\hline Total chlorine & $<1.0$ & $<1.0$ & $<1.0$ & $<1.0$ \\
\hline Hydrogen sulphide & $<1.0$ & $<1.0$ & $<1.0$ & $<1.0$ \\
\hline
\end{tabular}

Table 4: levels of harmful substances in digester gas analysis (all measurements in $\mathrm{mg} / \mathrm{m}^{3}$ )

Analysis contains levels of harmful substances in unrefined as well as raw gas measured at four different times. Siloxans levels in unrefined gas reach maximum levels of almost $3.7 \mathrm{mg} / \mathrm{m}^{3}$ before the gas cleaning phase. Increasing levels of siloxans are due to the high usage of detergents ( anti-foam agents) and growing demand for cosmetics (carrier materials). Siloxans develop silicon dioxide $\left(\mathrm{SiO}_{2}\right)$ when burned in the gas room with the help of oxygen. Resulting crystals are continuously added to the burning room which causes a decrease in efficiency or can lead to the destruction of the plant.

Siloxans were no longer found present in unrefined gas except for the sample on 11.14.00.

Organic silicon, with a maximum level of $1.4 \mathrm{mg} / \mathrm{m}^{3}$ in raw gas, was completely removed after the cleaning process. There is a considerable removal of hydrogen sulphide and sulphur emissions in the digester gas cleaning plant. Although there were still maximum levels of sulphur $40 \mathrm{mg} / \mathrm{m}^{3}$ and hydrogen sulphide $43 \mathrm{mg} / \mathrm{m}^{3}$ in raw gas, these levels of harmful substances could no longer be detected in refined gas. 


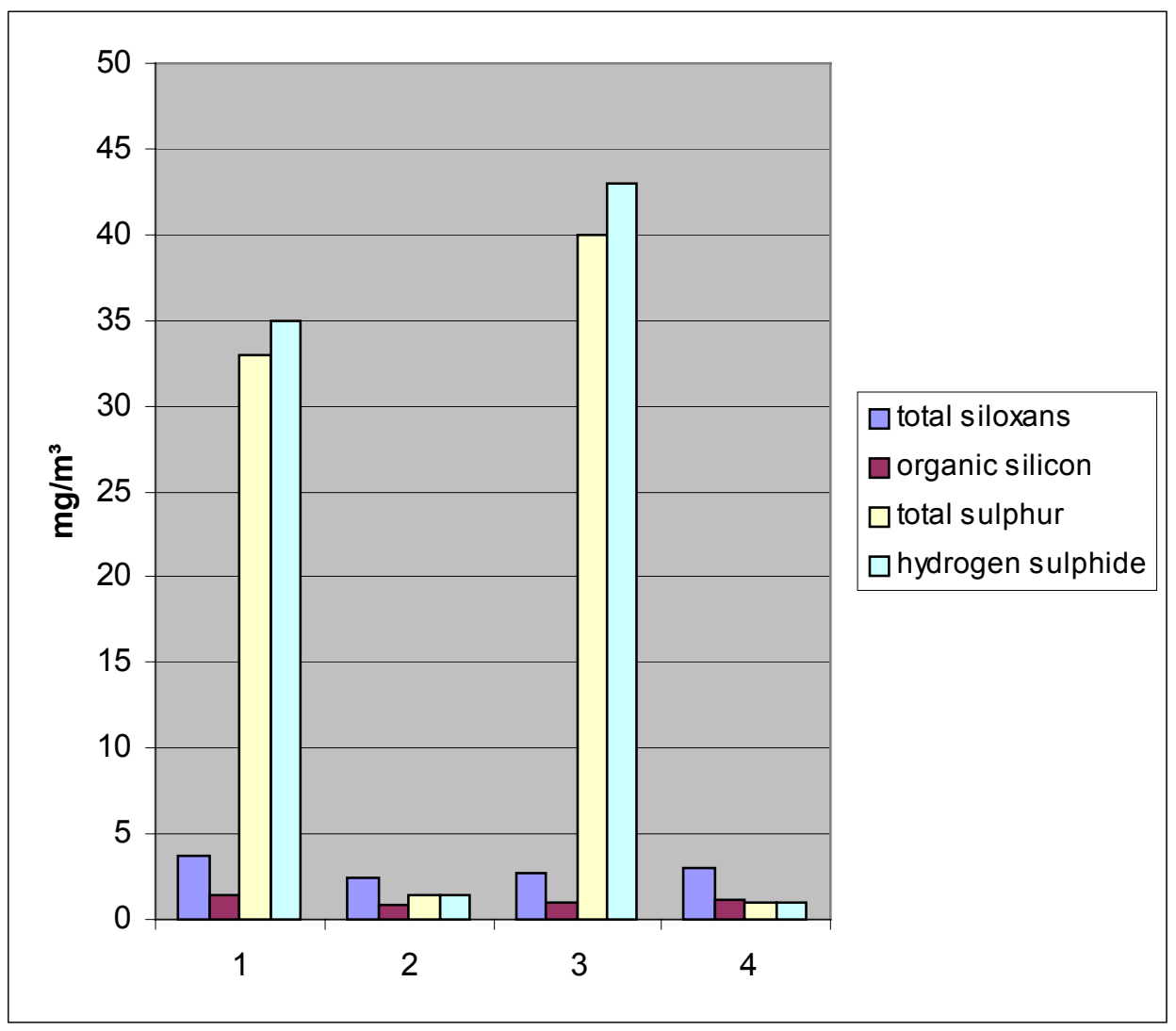

Diagram 6: Concentration of raw gas (4 readings)

Diagram 6 shows the emission levels of raw gas before the gas cleaning phase. Measurements of refined gas confirmed the excellent cleaning capacity of the plant. No emission levels were recorded in refined gas at the end of the cleaning phase apart from the slightest levels of organic silicon. Plant construction guarantees that the process engineering pollution limits necessary will be adhered to. Positive operational results show that, with sufficient gas cleaning, it is possible to use biogenetic gases in the fuel cell.

\subsection{Emissions in the total plant}

The amount of oxygen present in processed gas is an important parameter for the use of biogas ( e.g. digester gas) in a fuel cell. The limit for the PC25C is $1.3 \mathrm{Vol.-} \%$. However, due to the fact that leaks in fermentation power have meant that these limits have been exceeded twice, this process has resulted in the automatic shutdown of the fuel cell plant. Until now shutdowns have not caused any degradation of the cell voltage. 
The plant runs practically emission-free, as expected. The following table shows the results of emission measurements with a nominal load.

\begin{tabular}{||l|l|l|l||}
\hline & $\begin{array}{l}\text { Cellstack } \\
\text { (cathode waste gas) }\end{array}$ & Reformer burner & $\begin{array}{l}\text { Totalplant } \\
\text { according to TA-Luft }\end{array}$ \\
\hline $\mathrm{NO}_{\mathrm{x}}$ & $1 \mathrm{ppm}$ & $3 \mathrm{ppm}$ & $<5 \mathrm{mg} / \mathrm{m}^{3}$ \\
\hline $\mathrm{CO}$ & $0 \mathrm{ppm}$ & $15 \mathrm{ppm}$ & $<5 \mathrm{mg} / \mathrm{m}^{3}$ \\
\hline
\end{tabular}

* refers to $5 \% \mathrm{O}_{2}$-content in waste gas

Table 5: Emission reading results

\subsection{Phosphoric acid fuel cell}

\subsubsection{Effectiveness of productivity}

The electrical effectiveness of the cell stack is somewhat lower using reformed digester gas than when using natural gas. This is due to the lower concentration of hydrogen in anodic gas.

If the fuel cell is operated dynamically at various capacities, electrical effectiveness is changed. In the following section, the dependency of effectiveness on various capacity results (areas of part-load) should be examined using available data.

The operating data is composed of fuel cell capacity in $\mathrm{kW}$, the adjusted gas throughput and the proportion of methane in vol.-\% in the digester gas. The dependency of effectiveness on capacity and the relative gas throughput involved should both be determined from the available operating data. The calculation of effectiveness is solely based on dry gas throughput. The following levels were measured: 


\begin{tabular}{|c|c|c|c|}
\hline $\begin{array}{l}\text { Capacity } \\
{[\mathrm{kW}]}\end{array}$ & $\begin{array}{l}\text { Gas throughput } \\
\text { moist } \\
{\left[\mathrm{m}^{3} / \mathrm{h}\right]}\end{array}$ & $\begin{array}{l}\text { Gas throughput } \\
\text { dry } \\
{\left[\mathrm{m}^{3} / \mathrm{h}\right]}\end{array}$ & $\begin{array}{l}\text { Methane share } \\
{[\%]}\end{array}$ \\
\hline 200 & 91 & 80 & 63.2 \\
\hline 190 & 82 & 77 & 62.9 \\
\hline 180 & 78 & 72 & 62.9 \\
\hline 170 & 74 & 69 & 62.7 \\
\hline 160 & 69 & 64 & 63.0 \\
\hline 150 & 65 & 60 & 62.9 \\
\hline 140 & 61 & 56 & 62.7 \\
\hline 130 & 56 & 52 & 62.5 \\
\hline 120 & 52 & 48 & 62.4 \\
\hline 110 & 48 & 43 & 63.0 \\
\hline
\end{tabular}

Table 6: results measured

In order to carry out these calculations, the whole system is perceived as a Black-Box model. The balance limits are only shown at the entrance and exit of the system. The entrance parameter is the raw gas used to generate energy.

The methane share of digester gas is the sole contributor to the generation of energy in the fuel cell. On entering the system, raw gas is composed of some $65 \%$ methane and $35 \%$ carbon dioxide. The resulting methane share is included in the energy balance. The exit parameter consists of the electrical capacity of the fuel cell generated by electrochemical reactions.

The electrical losses caused by the compressor and gas cleaning device must be taken into account in the complete system When examined in detail, losses caused by the compressor amount to $1 \mathrm{~kW}$ and from gas cleaning to $3.5 \mathrm{~kW}$. Balance limits are based on the input side (raw gas) and the output side (electrical capacity). The components in between are seen as black box.

\section{Definition of effectiveness}

Electrical effectiveness is based on the quotients of a system's given capacity to its accepted capacity. The calculation is deduced from available results which are used in the formula. 
Results provided:

1) lower calorific value of methane $H_{u}: 36192 \mathrm{~kJ} / \mathrm{m}^{3}$

2) total loss (energy supply) of gas cleaning device: $\underline{4.5 \mathrm{~kW}}$

Total evaluation comprises of ten measurements all together. The calculation produced the following results:

\begin{tabular}{|c|c|c|c|}
\hline Capacity & Gas throughput & Methane share & effectiveness \\
\hline$[\mathrm{kW}]$ & {$\left[\mathrm{m}^{3} / \mathrm{h}\right]$} & {$[$ Vol.-\%] } & {$[\%]$} \\
\hline 200 & 91 & 63.2 & 38.3 \\
\hline 190 & 82 & 62.9 & 38.2 \\
\hline 180 & 78 & 62.9 & 38.5 \\
\hline 170 & 74 & 62.7 & 38.1 \\
\hline 160 & 69 & 63.0 & 38.2 \\
\hline 150 & 65 & 62.9 & 38.4 \\
\hline 140 & 61 & 62.7 & 38.6 \\
\hline 130 & 56 & 62.5 & 38.1 \\
\hline 120 & 52 & 62.4 & 38.3 \\
\hline 110 & 48 & 63.0 & 38.5 \\
\hline
\end{tabular}

Table 7: processed data

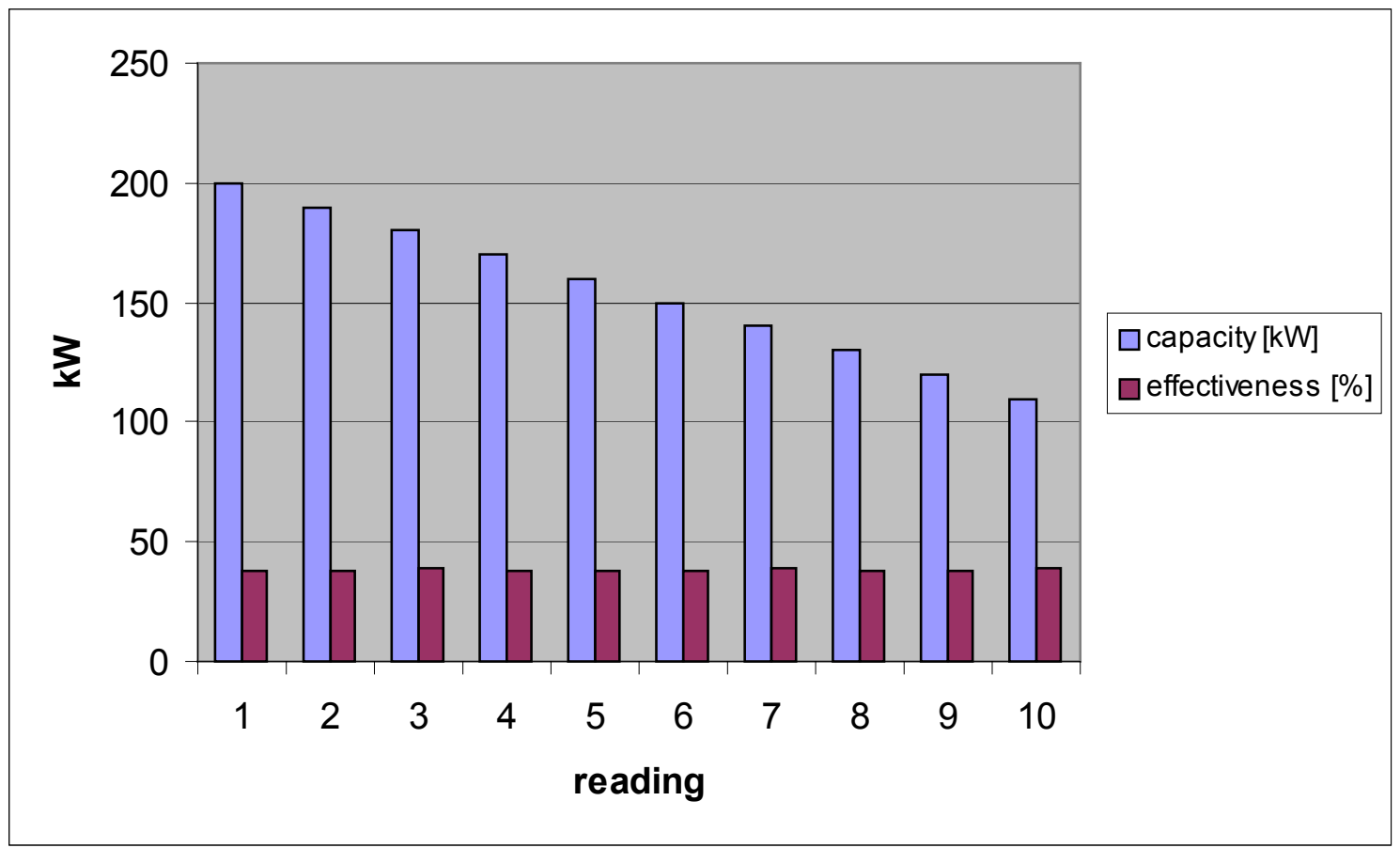

Diagram 7: Comparison between effectiveness and capacity 
In the diagram, we can see that the effectiveness of the overall plant shows a constant reaction independent from the dynamically varied capacity levels of the phosphoric acid fuel cell.

Here we have a considerable advantage from the fuel cell. Using conventional energy generating systems, the effectiveness of the part load regarding the complete load (maximum capacity) is considerably reduced. There is also a constantly high level of effectiveness from the fuel cell with a part load.

However, the electrical effectiveness calculated from the phosphoric acid fuel cell is up to $40 \%$ lower than generally expected. The reason for this is that there is a higher portion of own electricity needed for gas cleaning compared with the purely natural gas operation of a PAFC. This theoretically reduces total effectiveness.

If the fuel cell is operated at below $25 \%$ of electrical electic power at almost $200 \mathrm{~kW}$, effectiveness would be significantly reduced. This is connected to the fact that the use of own-energy by the periphery of the process at a lower capacity is considerably more noticeable than at a higher capacity.

\subsubsection{Degradation of cell voltage}

Due to the degradation process, the cell voltage of the phosphoric acid fuel cell PC25C is noticeably reduced when operational times are increased. The chemical aging process of the individual cells plays an important role here.

The electrolytes and highly-concentrated phosphoric acid used in the fuel cell have a certain volatility which takes them out of the cell with hot cathode exit gas. Yet the rate of taking out phosphoric acid is relatively high. Measurements of a research plant showed that after some 10,000 hours of operating, $8 \mathrm{~kg}$ of phosphoric acid had already been taken out.

The more hours of operation, the quicker the phosphoric acid is carried out. This is supposedly caused by the pollution of processed gas, particularly the ammoniac content. Approximately $70 \%$ of the ammoniac content in anodic fuel gas is absorbed by the phosphoric acid in the cell. From this, either light, volatile ammoniumhydrogenionphosphate $\left(\mathrm{NH}_{4} \mathrm{H}_{2} \mathrm{PO}_{4}\right)$ or amidic phosphoric acid. The chemical compounds strengthen the transportation of phosphoric acid. 
Another reason for degradation is the gradual decomposition of nano-dispense $\mathrm{Pt} / \mathrm{Co} / \mathrm{Cr}$-alloy catalysts carried by activated carbon. Compared with cathode power, the relatively high anodic power becomes more positive with a reduction of cell capacity (reduction in the system capacity with the electic power of $200 \mathrm{~kW}$ ). On the basis of this, when we switch off the whole system, there is a serious approach to the potential balance of oxygen which oxidises the platinum surface to platinum oxide (PtO). Due to the fact that platinum oxide has a finite solubility in phosphoric acid, the recrystallization, coarsening and surface-loss of nano-dispense precious metal is supported by the dissolving and reprecipitation of oxides and metal.

Activated carbon carries the catalyst and is not thermodynamically stable for the working potential of the cathode. Activated carbon is slowly anodically oxidised with this potential. This results in the carrier being anodically burned as operating hours are increased [7].

Measurements were taken in the Cologne-Rodenkirche fuel cell plant during the period of 03.08.00 - 04.27.01. From a multitude of results, those chosen were able to provide meaningful interpretations of the operation process.

The task at hand is to evaluate and clarify the dependency of cell voltage degradation on the hours worked in the plant. A slow reduction in the cell voltage of the phosphoric acid fuel cell PC25C is recorded with increasing working hours in the plant.

Cell voltage (DC) has already fallen by 5.5 volts in the period of 500 to 4,000 working hours. The great drop in cell voltage in the beginning is caused by a fault in the cathode air supply of the fuel cell. When it has been repaired, a new increase in cell voltage can be monitored. 


\begin{tabular}{|c|c|c|c|}
\hline Date & Net capacity & $\begin{array}{c}\text { Hours of opera- } \\
\text { tion }\end{array}$ & Cell voltage \\
\hline & {$[\mathrm{kW}]$} & {$[\mathrm{h}]$} & [VDC] \\
\hline 03.26 .00 & 150.02 & 506 & 167.3 \\
\hline 05.08 .00 & 149.61 & 653 & 166.3 \\
\hline 06.08 .00 & 169.84 & 654 & 167.0 \\
\hline 06.13 .00 & 139.25 & 771 & 167.0 \\
\hline 06.20 .00 & 140.01 & 935 & 166.5 \\
\hline 07.01 .00 & 125.24 & 1043 & 165.8 \\
\hline 07.06 .00 & 150.07 & 1075 & 166.6 \\
\hline 07.11 .00 & 124.92 & 1198 & 165.1 \\
\hline 07.18 .00 & 130.07 & 1376 & 166.4 \\
\hline 07.27 .00 & 120.21 & 1574 & 165.9 \\
\hline 08.03 .00 & 129.93 & 1740 & 165.8 \\
\hline 08.14 .00 & 120.45 & 2017 & 165.7 \\
\hline 08.23 .00 & 125.24 & 2237 & 166.1 \\
\hline 08.27 .00 & 100.14 & 2328 & 165.8 \\
\hline 08.31 .00 & 130.02 & 2419 & 165.6 \\
\hline 09.10 .00 & 129.93 & 2661 & 166.0 \\
\hline 09.17 .00 & 129.85 & 2828 & 165.0 \\
\hline 09.25 .00 & 140.01 & 3028 & 165.2 \\
\hline 10.04 .00 & 169.61 & 3240 & 164.9 \\
\hline 10.12 .00 & 149.65 & 3431 & 163.9 \\
\hline 10.31 .00 & 169.99 & 3830 & 162.7 \\
\hline 11.08 .00 & 150.02 & 4029 & 161.8 \\
\hline
\end{tabular}

Table 8: Evaluated results of the fuel cell plant

It can generally be said that every switching-off of the whole plant causes an insignificant voltage degradation and should be minimised to the greatest possible extent. Diagram 10 clearly shows the degradation of the cell voltage dependent on the amount of working hours completed.

Operational data also shows the dependency of cell voltage on the net capacity of the fuel cell. A reduction in the electrical net capacity leads to an increase in cell voltage due to the falling electricity density per cell. However, cell voltage must not fall below a fixed voltage level. If this cell voltage is reached, due to the aging process of the cell, the plant will not simply be switched off but will continue to operate at a lower capacity. 


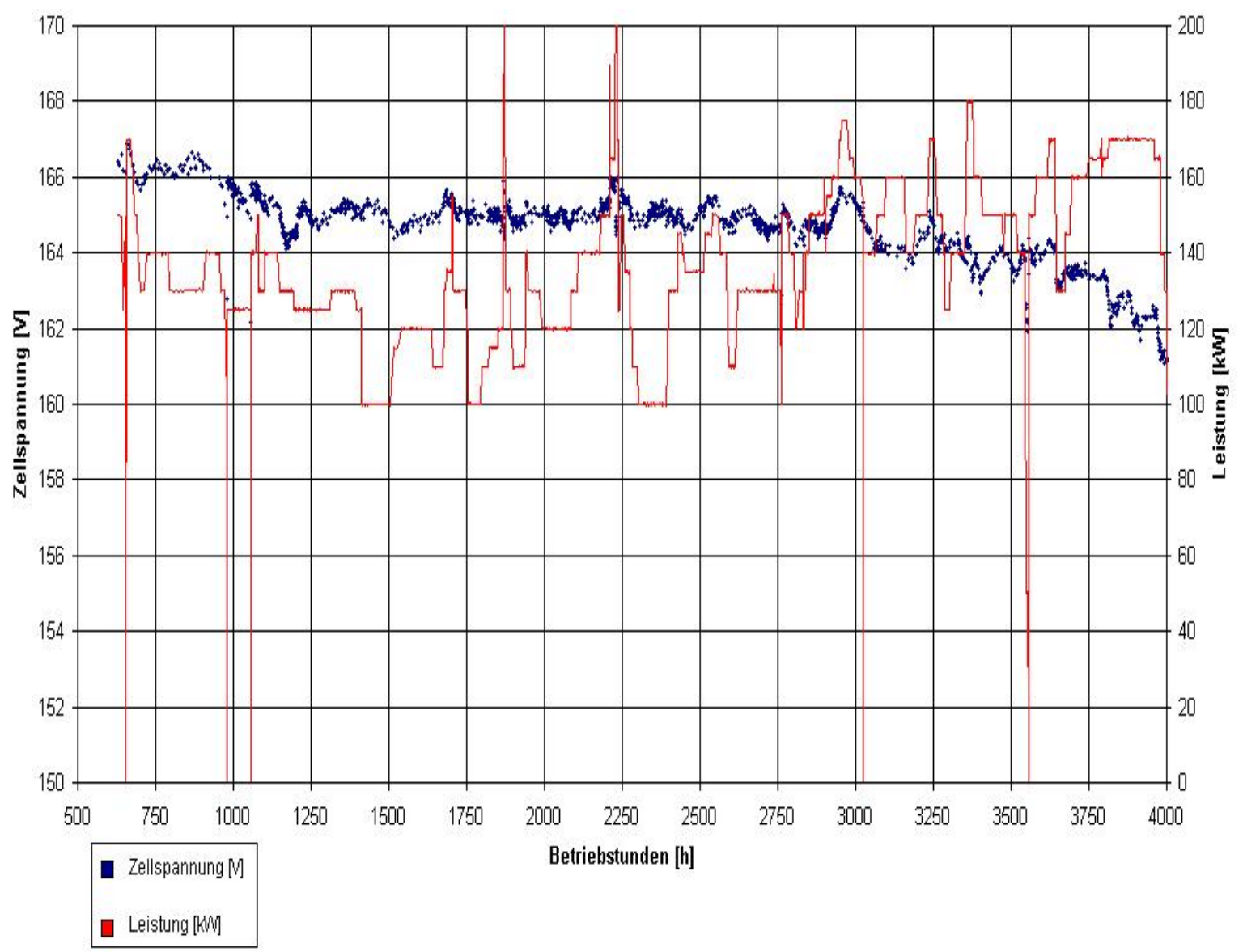

Diagram 8: Dependency of cell voltage on hours worked; Extrapolated at $200 \mathrm{~kW}$ (Zellspannung = cell voltage; Leistung = capacity; Betriebsstunden = Working hours $)$

The manufacturer of the phosphoric acid fuel cell PC25C, International Fuel Cells (IFC), recommends that the whole cell stack be exchanged after some 40,000 plant working hours. The manufacturer of fuel cells will have to face the challenge in the future of slowing down the aging process of the cell stack by developing the research of materials and, as a result, be able to compete with the cost reductions of conventional energy generating systems.

At the moment the cell stack, which has to be exchanged every 5 years, creates costs as high as approx. $500 \$ / \mathrm{kW}$. 


\subsubsection{Reliability Statistics}

The availability of an operating plant is an important indicator of the efficiency of the plant. Working hours completed without interruption are compared here with the loss of hours of the whole plant. Availability does not only refer here to the energy generating system itself but also consists of any periphery of the process that is necessary to maintain the problem-free operation of the plant.

The greater the complexity of the plant concept, the greater the danger is that the individual components will break down which, in the end, can lead to a decline in availability.

The following operating data was ascertained (overview):

\begin{tabular}{|c|c|c|c|}
\hline $\begin{array}{l}\text { Time period } \\
\text { From...to }\end{array}$ & $\begin{array}{l}\text { Operati- } \\
\text { on[min] }\end{array}$ & $\begin{array}{l}\text { Stoppage } \\
{[\mathrm{h}]:[\mathrm{min}]}\end{array}$ & $\begin{array}{l}\text { Cause } \\
\text { System }\end{array}$ \\
\hline \multicolumn{4}{|l|}{ 03.08.00 14:57 } \\
\hline $03.12 .0014: 13$ & $95: 16$ & & \\
\hline 03.14.00 15:45 & & $49: 32$ & Gas cleaning \\
\hline 03.27.00 17:00 & $313: 15$ & & \\
\hline 05.03.00 14:14 & & $885: 14$ & Digester gas plant \\
\hline 05.08.00 18:37 & $124: 23$ & & \\
\hline $06.08 .0015: 54$ & & $741: 17$ & Gas cleaning \\
\hline $06.22 .0004: 43$ & $324: 49$ & & \\
\hline $06.28 .0011: 47$ & & 151:04 & Digester gas plant \\
\hline $07.01 .0016: 58$ & $77: 11$ & & \\
\hline 07.05.00 12:18 & & $91: 20$ & Gas cleaning \\
\hline 09.25.00 11:59 & 1967:41 & & \\
\hline $09.25 .0015: 18$ & & $3: 19$ & Digester gas plant \\
\hline $10.17 .0018: 31$ & $531: 13$ & & \\
\hline $10.19 .0015: 24$ & & $44: 53$ & Digester gas plant \\
\hline 11.17.00 08:15 & $688: 51$ & & \\
\hline $11.17 .0014: 33$ & & $6: 18$ & Fuel cell \\
\hline $12.12 .0007: 44$ & $593: 11$ & & \\
\hline $12.12 .0009: 51$ & & 2:07 & Digester gas plant \\
\hline $04.27 .0117: 11$ & $3271: 20$ & & (present level) \\
\hline
\end{tabular}

Table 9: Periods of operation and stopppage of the fuel cell plant 
The fuel cell device in the Cologne-Rodenkirchen sewage plant consists of the fuel cell itself as well as an extensive periphery like gas processing, reformer and converter which are necessary for the problem-free implementation of energy generation.

\begin{tabular}{|c|c|c|c|c|c|c|c|c|c|}
\hline Remarks & Date & Loadtime & S/D type & Run hours & $\begin{array}{c}\text { S/D } \\
\text { Hours }\end{array}$ & M S/D & A S/D & $\begin{array}{l}\mathrm{RSH} / \\
\mathrm{SOH}\end{array}$ & $\mathrm{FOH}$ \\
\hline First start up & $08.03 .0014: 57$ & 123 & & & & 0 & 0 & & \\
\hline $\begin{array}{l}\text { GPU - motor starter } \\
\text { tripped, wrong } \\
\text { settings } \\
\text { P/P start }\end{array}$ & $14.03 .0015: 45$ & 218 & A & $95: 16$ & $49: 32$ & 0 & 1 & & $49: 32$ \\
\hline $\begin{array}{l}\text { Site works not } \\
\text { related to fuel cell } \\
\text { system (standby) } \\
\text { P/P start }\end{array}$ & $\begin{array}{l}27.03 .0017: 00 \\
03.05 .0014: 14\end{array}$ & 529 & M & $313: 15$ & $885: 14$ & 1 & 0 & $885: 14$ & \\
\hline $\begin{array}{l}\text { GPU - wrong valve } \\
\text { timing, both fuel } \\
\text { lines closed } \\
\text { P/P start }\end{array}$ & $\begin{array}{c}08.05 .0018: 37 \\
08.06 .0015: 54\end{array}$ & 653 & A & $124: 23$ & $741: 17$ & 0 & 0 & & $741: 17$ \\
\hline $\begin{array}{l}\text { Air in fuel gas }(2.5 \% \\
\text { Oxygen) } \\
\text { P/P start }\end{array}$ & $\begin{array}{l}22.06 .0004: 43 \\
28.06 .0011: 47\end{array}$ & $\begin{array}{l}978 \\
978\end{array}$ & A & $324: 49$ & 151:04 & $\begin{array}{l}0 \\
0\end{array}$ & $\begin{array}{l}1 \\
0\end{array}$ & & $151: 04$ \\
\hline $\begin{array}{l}\text { GPU - defective } \\
\text { relay } \\
\text { P/P start }\end{array}$ & $\begin{array}{r}01.07 .0016: 58 \\
05.07 .0012: 18\end{array}$ & $\begin{array}{l}1056 \\
1056\end{array}$ & A & $77: 11$ & $91: 20$ & $\begin{array}{l}0 \\
0\end{array}$ & $\begin{array}{l}1 \\
0\end{array}$ & & $91: 20$ \\
\hline $\begin{array}{l}\text { GPU - lack of coo- } \\
\text { ling water supply } \\
\text { Hot restart }\end{array}$ & $\begin{array}{r}25.09 .0011: 58 \\
25.09 .0015: 18\end{array}$ & $\begin{array}{l}3024 \\
3024\end{array}$ & A & $1967: 40$ & $3: 20$ & $\begin{array}{l}0 \\
0\end{array}$ & $\begin{array}{l}1 \\
0\end{array}$ & & $3: 20$ \\
\hline $\begin{array}{l}\text { Air in fuel gas }(2.2 \% \\
\text { Oxygen }) \\
\text { P/P start }\end{array}$ & $\begin{array}{l}17.10 .0018: 31 \\
19.10 .0015: 24\end{array}$ & $\begin{array}{l}3555 \\
3555\end{array}$ & A & $531: 13$ & $44: 53$ & $\begin{array}{l}0 \\
0\end{array}$ & $\begin{array}{l}1 \\
0\end{array}$ & & $44: 53$ \\
\hline $\begin{array}{l}\text { Ripped process air } \\
\text { hose (scheduled) } \\
\text { P/P start }\end{array}$ & $\begin{array}{l}17.11 .0008: 15 \\
17.11 .0014: 33\end{array}$ & $\begin{array}{l}4245 \\
4245\end{array}$ & M & $688: 51$ & $6: 18$ & $\begin{array}{l}1 \\
0\end{array}$ & $\begin{array}{l}0 \\
0\end{array}$ & $6: 18$ & \\
\hline $\begin{array}{l}\text { GPU - lack of } \\
\text { cooling water } \\
\text { supply } \\
\text { Hot restart }\end{array}$ & $\begin{array}{l}12.12 .0007: 44 \\
12.12 .0009: 51\end{array}$ & 4838 & A & $593: 11$ & 2:07 & 0 & 1 & & 2:07 \\
\hline \multirow{2}{*}{$\begin{array}{l}\text { Present level (1st } \\
\text { year) }\end{array}$} & $27.04 .0117: 11$ & 7164 & & $3271: 20$ & & 0 & 0 & & \\
\hline & & & & & & 2 & 7 & $891: 32$ & $1083: 33$ \\
\hline
\end{tabular}

Table 10: added list for explaining the reliabilty statistics

\begin{tabular}{|l|r|r|}
\hline Reliability Performance Indices (as per GTI definitions): \\
\hline Period Hours (PH) & $9962: 14$ & $\mathrm{hrs}$ \\
Scheduled Outage Hours (SOH) & $6: 18$ & $\mathrm{hrs}$ \\
Forced Outage Hours (FOH) & $1083: 33$ & $\mathrm{hrs}$ \\
Reserve Standby Hours (RSH) & $885: 14$ & $\mathrm{hrs}$ \\
System Available - Available Hours (AH) & $8872: 23$ & $\mathrm{hrs}$ \\
System Operating Service Hours (SH) & $7987: 09$ & $\mathrm{hrs}$ \\
Period of Demand (POD) & $9070: 42$ & $\mathrm{hrs}$ \\
Availability Factor (AF) & 89,1 & $\%$ \\
Forced Outage Rate (FOR) & 11,9 & $\%$ \\
Scheduled Outage Factor (SOF) & 0,1 & $\%$ \\
Service Factor (SF) & 80,2 & $\%$ \\
Mean Time Between Forced Outages (MTBFO) & $1141: 01$ & $\mathrm{hrs}$ \\
Mean Down Time (MDT) & $121: 05$ & $\mathrm{hrs}$ \\
\hline
\end{tabular}

Table 11: Full reliabilty statistics 
Excurs: the following definitions explains the abbreviation before:

Definitions:

"There are various ways to measure reliability. In power generation systems, key measures of performance are availability and various maintenance-related indices. The following graphic illustrates different reliability categories for a given period of time (e.g., one year). A power generation system is characterized - depending on its operating state - to be in one of these conditions."

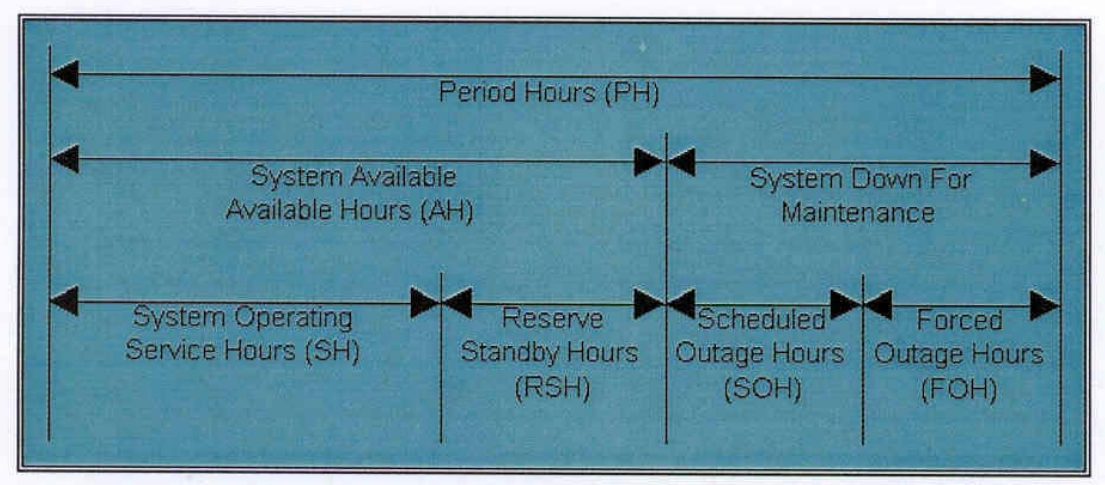

"A number of performance indices can be calculated based on operational and maintenance data."

\begin{tabular}{|c|c|}
\hline Reliability Performance Indices & Formula \\
\hline $\begin{array}{l}\text { Period of Demand }(P O D) \text { : } \\
\text { Measures the time the unit was planned to oper- } \\
\text { ate. }\end{array}$ & $P O D=P H-R S H-S O H$ \\
\hline $\begin{array}{l}\text { Availability Factor (AF, \%): } \\
\text { Measures, on a percent basis, the unit's "could } \\
\text { run" capability. Impacted by planned and un- } \\
\text { planned maintenance. }\end{array}$ & $A F=\frac{(P H-S O H-F O H) \times 100}{P H}$ \\
\hline $\begin{array}{l}\text { Forced Outage Rate (FOR, \%): } \\
\text { Measures portion of downtime due to unplanned } \\
\text { factors. }\end{array}$ & $F O R=\frac{F O H \times 100}{S H+F O H}$ \\
\hline $\begin{array}{l}\text { Scheduled Outage Factor (SOF, \%): } \\
\text { Measures percent of time set aside for planned } \\
\text { maintenance. }\end{array}$ & $S O F=\frac{S O H \times 100}{P H}$ \\
\hline $\begin{array}{l}\text { Service Factor (SF, \%): } \\
\text { Percent of total period hours the unit is on-line- } \\
\text { varies due to site-related or economic factors. }\end{array}$ & $S F=\frac{S H \times 100}{P H}$ \\
\hline $\begin{array}{l}\text { Mean Time Between Forced Outages } \\
\text { (MTBFO): Measures the nominal time between } \\
\text { unscheduled forced outages. }\end{array}$ & $M T B F O=\frac{S H}{\# \text { ForcedOutages }}$ \\
\hline $\begin{array}{l}\text { Mean Down Time (MDT): } \\
\text { Measures the nominal duration the unit is down } \\
\text { during maintenance events. }\end{array}$ & $M D T=\frac{S O H+F O H}{\# \text { ForcedOutages }+\# \text { PlannedOutages }}$ \\
\hline
\end{tabular}




\section{Calculation of special availabilities}

The calculation of availability is carried out as follows :

$$
\text { Availability }=\frac{\sum \text { OperationalHours }}{\sum \text { OperationalHours }+\sum \text { Interruptions }}
$$

\begin{tabular}{|l|c|}
\hline $\begin{array}{l}\text { Availability from first operation } \\
\text { (operation time/calender) }\end{array}$ & $80.20 \%$ \\
\hline $\begin{array}{l}\text { Availability from 06.01.2000 } \\
\text { (beginning of world exhibition EXPO 2000) }\end{array}$ & $93.90 \%$ \\
\hline $\begin{array}{l}\text { Availability of fuell cell system } \\
\text { Since 06.01.2000 }\end{array}$ & $96.50 \%$ \\
\hline \begin{tabular}{l} 
Availability of the fuel cell stack \\
\hline
\end{tabular} & $99.90 \%$ \\
\hline
\end{tabular}

Table 10: Availability of the fuel cell plant

According to the manufacturing instructions of the company International Fuel Cells (IFC), the availability of the whole fuel cell plant can amount to as much as $95 \%$. The availability of the phosphoric acid fuel cell PC25C is noticeably high at almost $100 \%$.

Since the fuel cell started operating, there has only been one fault. This was caused by a leak in the cathode air supply. The further five times when the whole plant was switched-off were caused during the starting phase of the fuel cell or by faults in the conventional plant components.

Until now, only the periphery of the process has caused an operational interruption due to stopppage which has then meant a reduction in plant availability.

Result: Operating data prove that the whole system has very high availability and the fuel cell itself has an extraordinarily high availability. 


\subsubsection{Thermal Output}

The chart below depicts the fuell utilization of ther PC $25 \mathrm{C}$ fuell cell power plant at the wastewater treatment plant in Köln-Rodenkirchen, based on measurements taken throughout the first year of operation. The heat output with a temperature of $60^{\circ} \mathrm{C}$ is used to heat the digester sludge before it is pump in the digester tower.

\section{Fuel Utilization PC25C at the wastewater treatment plant Koeln-Rodenkirchen}

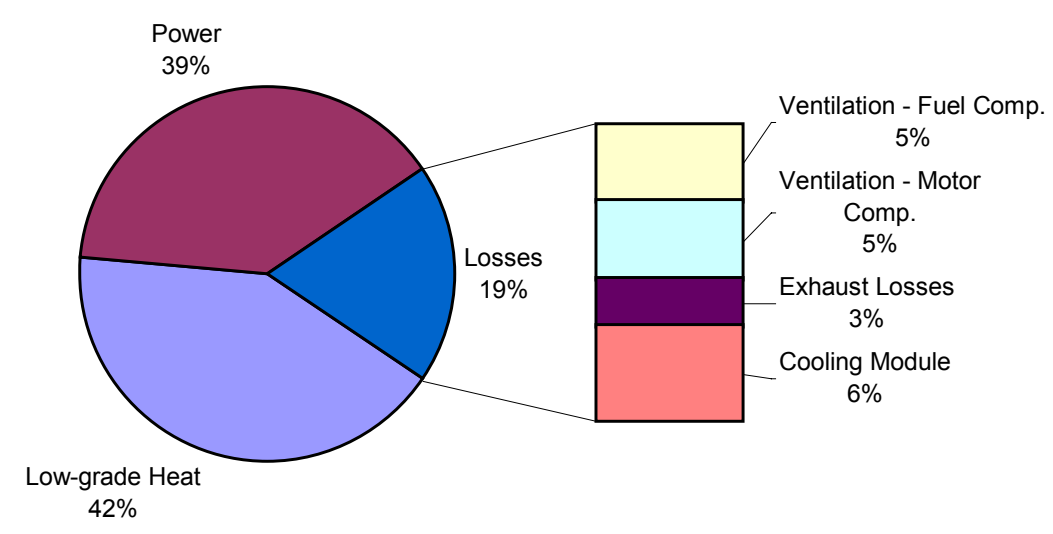

Diagram 9: Fuell Utilization

The countercurrent temperature is $40^{\circ} \mathrm{C}$. Measurements have shown that the relative emission of heat increases at higher electrical capacity. However, the ratio of $200 \mathrm{~kW}$ electricity to $205 \mathrm{~kW}$ heat is confirmed on the whole with the respective production amounts of electricity and heat.

From September to March, all of the heat produced is needed to pre-heat the sludge. From March to September, waste water has a higher temperature and the additional heat needed to pre-heat the sludge is lower. However, in this case, surplus heat can be used to heat processed water in the sewage plant.

A total fuel utilization of $81 \%$ has in practic achieved. 


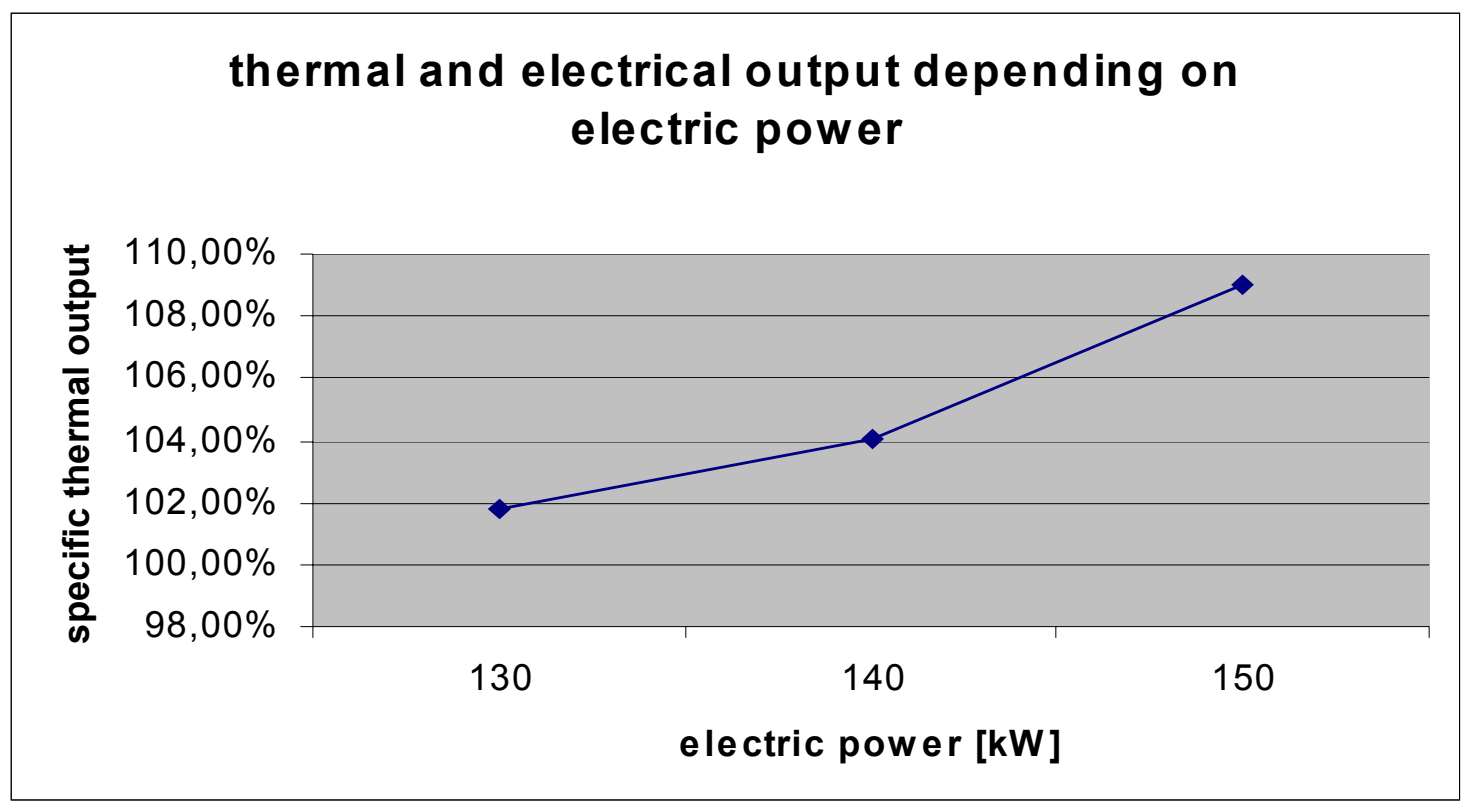

Diagram 10: Electric power and the specific thermal output (electic output in each case $100 \%$ )

\subsubsection{Cost Benefit Analysis}

The following tables provide the economic data from the first year of operation. All costs have been converted into U.S. Dollars, based on the exchange rate of 1 US $\$=$ 1,80 DM, which was fixed when the Contract of Sale became effective in May 1999.

\section{Economic considerations (costs)}

The following marginal conditions form the basis of the economic analysis:

- Due to the fact that a heating system to heat the sludge is at imminent disposal, those costs related to the running of the heating system and the reduced level of wear and tear are thus saved. As a result, heat proceeds are fixed at 0,3 cents/kWh.

- Proceeds derived from selling the electricity are guaranteed for a period of 20 years by the Federal Law „Erneuerbare-Energien-Gesetz EEG." This compensation is made use of by methods of cost redistribution by the GEW as an electricity supplier.

- Conservative assumptions are made regarding the electricity and heat proceeds („average performance“) and correspond to the plant's teaching character.

- 3 variants will be tested at different running times in the overall plant, dependant on the stack-change required.

- The fuel is free as it is obtained as a waste-product from sewage-cleaning. 
The guidelines of the Association of German Engineers VDI 2067 serve as a basis for calculating the costs incurred.

\begin{tabular}{|l|l|}
\hline Calculation interest rate & $8.4 \%$ \\
\hline Annual running-time of plant & $7,500 \mathrm{~h} / \mathrm{a}$ \\
\hline Life according to variant & $5 \mathrm{a} / 10 \mathrm{a} / 15 \mathrm{a}$ \\
\hline Heat credit & $0.3 \$$ cents/kWh \\
\hline Electricity credit (statutory compensation) & $7.0 \$$ cents/kWh \\
\hline Electrical nominal and average capacity & $200 \mathrm{~kW} / 150 \mathrm{~kW}$ \\
\hline Annual electricity production & $\mathbf{1 , 1 2 5 , 0 0 0 ~ k W h / a}$ \\
\hline Nominal-heat capacity/average capacity & $205 \mathrm{~kW} / 154 \mathrm{~kW}$ \\
\hline Annual heat production & $\mathbf{1 , 1 5 5 , 0 0 0 ~} \mathbf{k W h} / \mathbf{a}$ \\
\hline
\end{tabular}

Table 12: calculation basic datas

A) Annual costs for investment management are made up of investments in plant components.

1. Variant: working time period of 5 years

\begin{tabular}{|c|c|c|c|c|}
\hline \multicolumn{5}{|c|}{ A Annual Costs for Investment Management } \\
\hline & $\begin{array}{l}\text { Power-heat } \mathrm{c} \\
\text { Based on a } \mathrm{f}\end{array}$ & $\begin{array}{l}\text { pling plar } \\
\text { cell with }\end{array}$ & s cleanin & \\
\hline \multirow[t]{2}{*}{ Plant-components } & Investment & Life & Annuity & Annual costs \\
\hline & $\$$ & Years [a] & $\%$ & $\$ / a$ \\
\hline $\begin{array}{l}\text { Fuel cell } \\
\text { Incl. Planning/transportation/ } \\
\text { Development/integration }\end{array}$ & $1,130,000$ & 5 & 25.31 & 286,000 \\
\hline $\begin{array}{l}\text { 1. Change of cell-stack } \\
\text { (after } 5 \text { years) }\end{array}$ & & 10 & & \\
\hline $\begin{array}{l}\text { 2. Change of cell-stack } \\
\text { (after } 10 \text { years) }\end{array}$ & & 15 & & \\
\hline Heat-exchanger & 77,000 & 5 & 25.31 & 19,500 \\
\hline Gas cleaning/gas return & 107,000 & 5 & 25.31 & 27,100 \\
\hline \multicolumn{5}{|l|}{ Funding } \\
\hline $\begin{array}{l}\text { Government } \\
\text { Of Northrhine-Westfalia }\end{array}$ & $-79,000$ & 5 & 25.31 & $-20,000$ \\
\hline U.S.-DOE & $-200,000$ & 5 & 25.31 & $-50,600$ \\
\hline TOTAL A & & & & 262,000 \\
\hline
\end{tabular}

Table 13: annual costs, 1 . variant 
2. Variant: working time period of 10 years

\begin{tabular}{|l|c|c|c|c|}
\hline \multirow{2}{*}{ A Annual Costs for Investment Management } \\
\hline & \multicolumn{4}{l}{$\begin{array}{l}\text { Power-heat coupling plant } \\
\text { Based on a fuel cell with gas cleaning }\end{array}$} \\
\hline & Investment & Life & Annuity & Annual costs \\
\cline { 2 - 5 } & $\$$ & Years [a] & $\%$ & $\$ / a$ \\
\hline $\begin{array}{l}\text { Fuel cell } \\
\text { Incl. Planning/transportation/ } \\
\text { Development/integration }\end{array}$ & $1,130,000$ & 10 & 15.17 & 171,400 \\
\hline $\begin{array}{l}\text { 1. Change of cell-stack (5 a) } \\
\text { 2. Change of cell-stack (10 a) }\end{array}$ & 100,000 & 5 & 25.31 & 25,300 \\
\hline Heat-exchanger & 77,000 & 10 & 15.17 & 11,700 \\
\hline Gas cleaning/gas return & 107,000 & 10 & 15.17 & 16,300 \\
\hline Funding & & & & \\
\hline $\begin{array}{l}\text { Government } \\
\text { of Northrhine-Westfalia }\end{array}$ & $-79,000$ & 5 & 15.17 & $-12,100$ \\
\hline U.S.-DOE & $-200,000$ & 5 & 15.17 & $-30,300$ \\
\hline TOTAL A & & & & 182,300 \\
\hline
\end{tabular}

Table 14: annual costs, 2. Variant

\section{Variant: working time period of $\mathbf{1 5}$ years}

\begin{tabular}{|c|c|c|c|c|}
\hline \multicolumn{5}{|c|}{ A Annual Costs for Investment Management } \\
\hline & $\begin{array}{l}\text { Power-heat c } \\
\text { based on a fu }\end{array}$ & $\begin{array}{l}\text { ling plant } \\
\text { ell with g }\end{array}$ & Eleaning & \\
\hline \multirow[t]{2}{*}{ Plant-components } & Investment & Life & Annuity & Annual costs \\
\hline & $\$$ & Years [a] & $\%$ & $\$ / a$ \\
\hline $\begin{array}{l}\text { Fuel cell } \\
\text { Incl. Planning/transportation } \\
\text { Development/integration }\end{array}$ & $1,130,000$ & 15 & 11.97 & 135,300 \\
\hline Change of cell-stack (5 a) & 100,000 & 10 & 15.17 & 15,200 \\
\hline Change of cell-stack (10 a) & 50,000 & 5 & 25.31 & 12,700 \\
\hline Heat-exchanger & 777,000 & 15 & 11.97 & (9,200 \\
\hline Gas cleaning/gas return & 107,000 & 15 & 11.97 & 12,800 \\
\hline \multicolumn{5}{|l|}{ Funding } \\
\hline $\begin{array}{l}\text { Government } \\
\text { of Northrhine-Westfalia }\end{array}$ & $-79,000$ & 5 & 11.97 & $-9,500$ \\
\hline U.S.-DOE & $-200,000$ & 5 & 11.97 & $-24,000$ \\
\hline TOTAL A & & & & 151,700 \\
\hline
\end{tabular}

Tabel 15: annual costs, 3. variant 
B) Annual consumption costs are incurred by fuel and other forms of energy. Total B amounts to 1,000 \$/a.

C) Annual operational costs are made up of:

\begin{tabular}{|l|c|}
\hline C Annual Operational Costs \\
\hline Cost centre & Annual costs \\
\cline { 2 - 2 } & $\$ / a$ \\
\hline Wages & 20,000 \\
\hline Maintenance/service & 20,000 \\
\hline Insurance/tax & 100 \\
\hline Fuel costs & 5,000 \\
\hline TOTAL B & $\mathbf{4 5 , 6 0 0}$ \\
\hline
\end{tabular}

Table 16: operational costs

The total annual costs of the fuel cell plant can be ascertained from the total sum of the costs for investment management, consumption costs and operational costs. In order to determine specific economic losses in cents/KWh, the plant capacity in $\mathrm{kW}$ and annual running-time are integrated in the calculation. Proceeds from the sale of electricity and heat are weighed against the costs. The formula for this is:

Specific loss $=$ (annual costs /annual electrical work $)-($ electricity proceeds + heat proceeds $)$

Proceeds calculated by electricity and heat generation come to approximately 82,000 \$/a.

\begin{tabular}{|l|c|c|}
\hline $\begin{array}{l}\text { Variant } \\
\text { (running-time) }\end{array}$ & $\begin{array}{c}\text { D Annual Costs } \\
\text { [\$/a] }(\text { Total } A+B+C)\end{array}$ & $\begin{array}{c}\text { Specific Loss } \\
\text { [cents/kWh electrical] }\end{array}$ \\
\hline 1. Variant (5 years) & 308,000 & 20.1 \\
\hline 2. Variant (10 years) & 228,900 & 13.1 \\
\hline 3. Variant (15 years) & 198,300 & 10.3 \\
\hline
\end{tabular}

Table 17: Comparison of variants and specific losses

Specific losses (negative proceeds from the sale of electricity) are mainly based on conservative assumptions regarding annual electricity and heat production. 


\section{Benefits}

The benefits for the GEW Köln AG from this investment are mainly in areas which cannot immediately be assessed in monetary terms. These include:

- Advantages from a gain in prestige and the resulting customer connections in a liberalized electricity market,

- Advantages obtained from the medium-term increase in know-how.

GEW is absolutely convinced that the fuel cell market is forward-looking and economically interesting.

However an advantage can be quantified today. The European Union Commission would like to enter a pilot-testing-phase of carbon-dioxide emission beginning in the year 2005. According to worldwide empirical reports, the $\mathrm{CO} 2$ market value fluctuates between 2 and $30 € /$ ton of carbon-dioxide.

Due to the fact that the electricity produced by the fuel cell is CO2-neutral, a current saving of approximately $0,6 \mathrm{~kg}$ can be calculated compared with the domestic average value of $\mathrm{CO} 2$ emission for a kilowatt hour of electricity. This corresponds to an emission credit of approximately 0,12 to 1,8 cents for every kilowatt hour of electrical energy generated in the fuel cell.

The pilot character of the plant must be considered when carrying out an economical analysis. Using digester gas to supply energy to a fuel cell is unique in Europe. Therefore, there are higher costs compared with other more established methods of technology. 


\section{CONCLUSION}

\section{Conclusions about the use of this type of fuel cell in sewage plants (estimation of potential)}

In sewage plants in Germany, accumulated biogas is frequently used for energy with the help of gas engines. The statistical Federal Office carried out an investigation in 1999 and this showed that digester gas was used for electricity generation in 608 sewage plants. 598 of these plants produce electricity to supply their own demand and a further 78 plants give their electricity production to the public mains.

The total amount of electricity generated adds up to $668.614 \mathrm{MWh}$ and is calculated using the average CHP-capacity (102 kW/plant). Operators of sewage plants have to consider the extent to which new technology can substitute for conventional gas engines in the future.

At the moment, the only commercially available phosphoric acid fuel cell is model PC25C produced by the company IFC (Connecticut/USA). It has an electrical capacity of $200 \mathrm{~kW}$ and a thermal capacity of $205 \mathrm{~kW}$. These results are based on the use of digester gas for energy supply.

However it is necessary to extend the size of the existing sewage plants to be able to use this type of fuel cell device. The capacity of the sewage plant is reflected according to the inhabitant equivalents. The phosphoric acid fuel cell PC25C, with a capacity of $200 \mathrm{~kW}$, can only be used in sewage plants with an extension size of more than 90,000 inhabitant equivalents.

In 1995, an investigation by the Institute for Housing Estates and Water-Supply showed the following extension sizes of sewage plants in Germany: 


\begin{tabular}{|c|c|}
\hline \multicolumn{2}{|c|}{$\begin{array}{l}\text { Extension size of sewage plants according to inhabi- } \\
\text { tant equivalents }\end{array}$} \\
\hline Inhabitant equivalents & Number of plants in Germany \\
\hline Less than 500 & 2569 \\
\hline $500-1000$ & 1539 \\
\hline $1000-2000$ & 1319 \\
\hline $2000-3000$ & 739 \\
\hline $3000-5000$ & 945 \\
\hline $5000-10000$ & 917 \\
\hline $10000-20000$ & 861 \\
\hline $20000-50000$ & 795 \\
\hline $50000-100000$ & 320 \\
\hline 100000 and more & 269 \\
\hline Total no. of plants & 9935 \\
\hline
\end{tabular}

Table 11: Inhabitant equivalents [8]

Therefore, based on the given capacity, the fuel cell PC25C is only suitable for use in 269 sewage plants with an extension size of 100,000 inhabitant equivalents and more.

For obvious reasons, producing fuel cells with a lower capacity could develop a larger market volume regarding sewage plants. As many as 1384 sewage plants could be equipped with a $100 \mathrm{~kW}$ plant model.

The possibilities are endless for the many ways of using the fuel cell to obtain electricity and heat from digester gas. A few reasons for this would be the diversification of fuel cell models, the modular extension of plants as well as series production expected in this decade with simultaneously increasing effectiveness. This assumption is based above all on the annual figures of the digester gas cleaning plant which supplies a good starting product for reforming fuel gas. Another positive factor is that there were no technical disruptions in the plant, connected to the fuel gas composition, in the first experience of operating for approximately 8,000 hours. 


\section{Conclusions for the operation of fuel cells from the viewpoint of an energy sup- ply company}

Fuel cells are pushing their way in to the market and it is certain that they will soon be competing with conventional systems of energy generation. GEW Köln AG faces the challenges of an energy service and supplier.

The advantages of the fuel cell can be seen, for example, with the PC25C model. A higher level of total effectiveness with simultaneously low emission levels present a useful perspective for the future especially regarding the tightened environmental conditions and more efficient use of energy.

As it is known that fossil resources are finite and the anthropogenetic hothouse effect warns us to be more economical, growing importance will be placed on using regenerated energy sources. The fuel cell has the job of transforming regeneratively generated hydrogen (here: from digester gas)with great efficiency and thus producing a useable form of electrical energy and heat.

Fuel cell technology is in a critical phase at the moment. The growing number of worldwide development efforts made by large as well as middle-class companies and extensive government aid programmes show the expectancy of innovative technology to achieve considerable market potential and solve problems in the energy economy and traffic sector.

Using fuel cells opens up new perspectives for considerably more ecologically harmless power sources for traffic as well as more efficient and ecologically advantageous plants for energy and heat coupling which is preferred for decentralized energy generation.

Requirements from fuel cells for vehicle use are low costs, small measurements and a light weight. However, when stationary they are more in the area of longer life and competitive costs.

The fuel cell presents a bridge to hydrogen economy. Hydrogen is first of all supplied by mainly fossil energy carriers. If the generation of storable hydrogen is successful on a large scale with the help of regenerative energies (biogases, bio-mass, wind-, water-, solar-, geothermal-energy) then the neutral climatic, sustained energy cycle shuts down. The concept of generating electricity and heat from bio-mass has already been 
put into action with the help of a fuel cell in the Cologne-Rodenkirchen sewage plant. It should show that this technology is already usable today and is able achieve the associated environmental goals.

Before it can be used on a wider scale, there must be more technical development and, above all, conclusions found for the existing economic gaps to be able to compete in a market of well-established systems.

The chances of the fuel cell entering and saturating the market are increased with the creation of a framework of relevant political conditions. As a market partner, the GEW Köln AG is initially interested in the economical production of electricity and heat. Therefore, it is watching exactly how the market is changing with respect to the fuel cell. The GEW Köln AG expects this technology to experience a market break-through before the end of this decade. 


\section{References}

[1] Product information

Fuel cell PC25C

Technical advice energy; IFC Cooperation

[2] Sewage plant Digital

CD-Rom of the city of Cologne

[4] www. members/technik.htm

[5] Fuel cells in the energy market

March 1996

Forum for Future Technologies, conference tape

ISBN 3-930157-28-4

[3] VDI Publisher

Hartmut Wendt and Vojtech Plzak

Fuel cells, Technological Situation, Development lines

ISBN 3-18-400996-3

[6] Product information

Handbook for gas cleaning in the Köln-Rodenkirchen sewage plant

Siloxa Engineering AG

[7] Chemical Engineering Technology

October 1997

Wiley-VCH Publisher

Page 1457-1462

[8] Federal Office Berlin

\section{List of Acronyms:}

$\mathrm{kW} \quad$ kilowatt $=3,600 \mathrm{~J} / \mathrm{s}$

$\mathrm{kWh}$ kilowatt hour $=3,600,000 \mathrm{~J}$

$\mu \mathrm{m} \quad \mathrm{m}^{-3}$

$\mathrm{m}^{3}{ }_{\mathrm{i} . \mathrm{N}} \quad$ standard cubic meter 


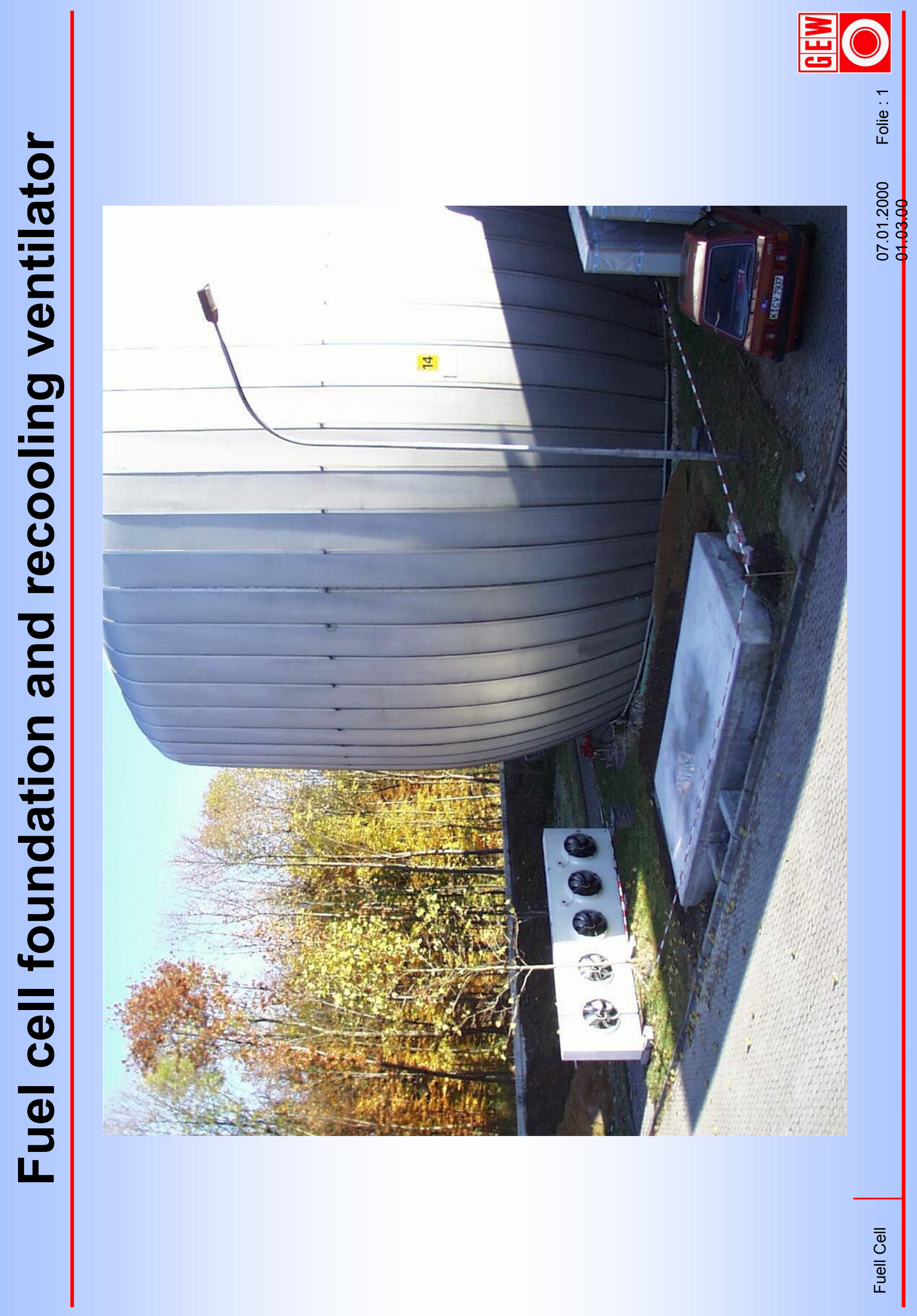




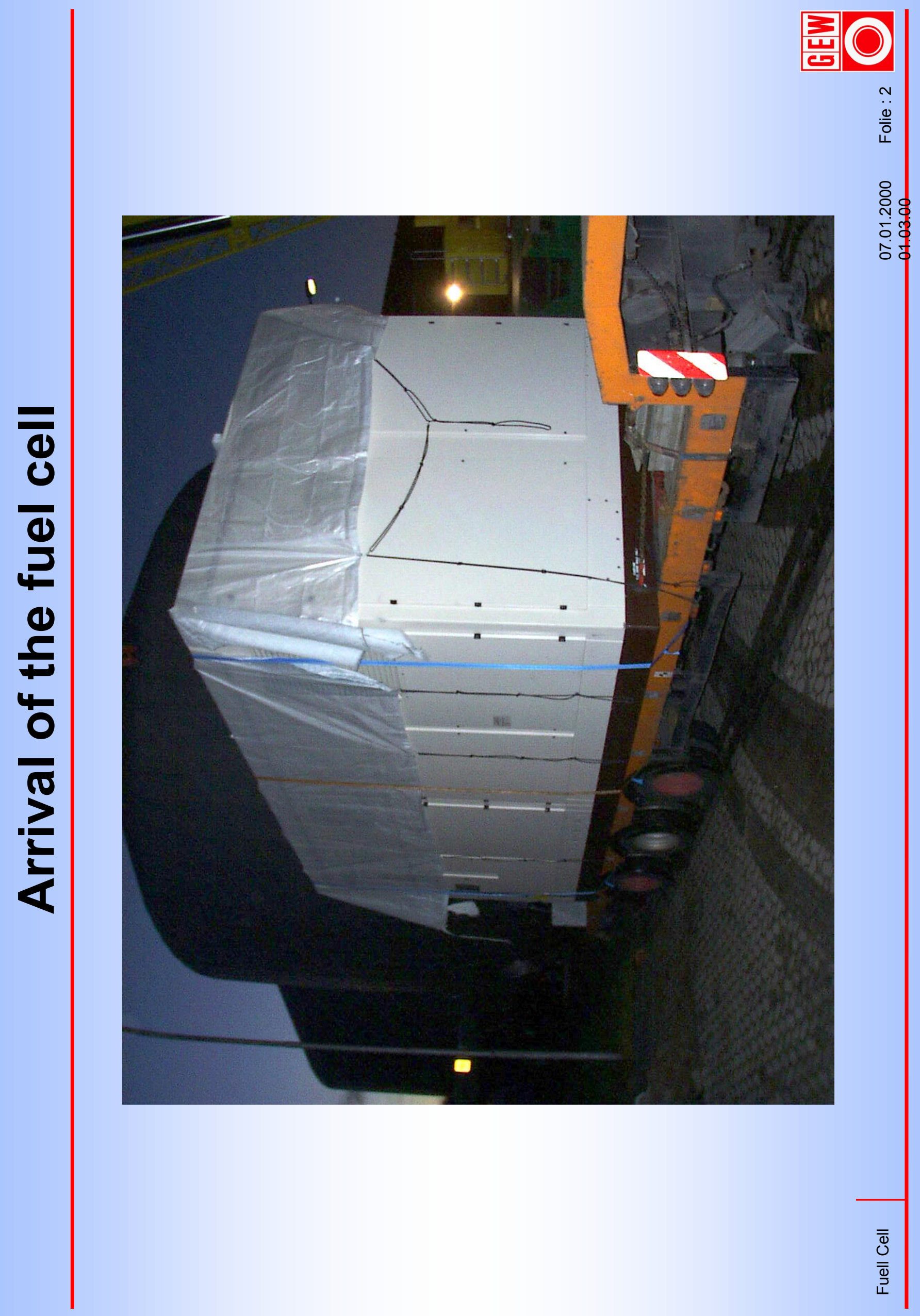




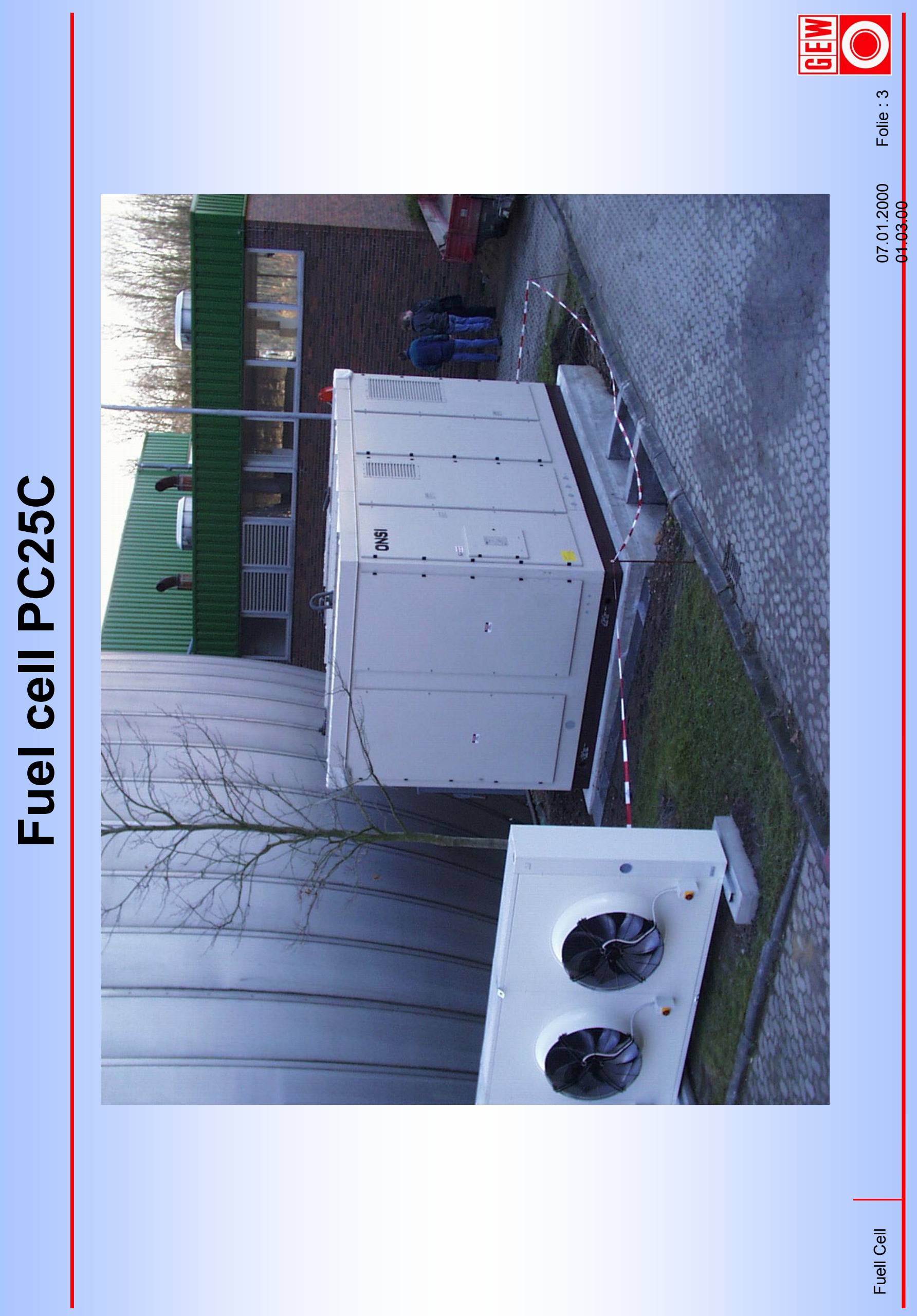




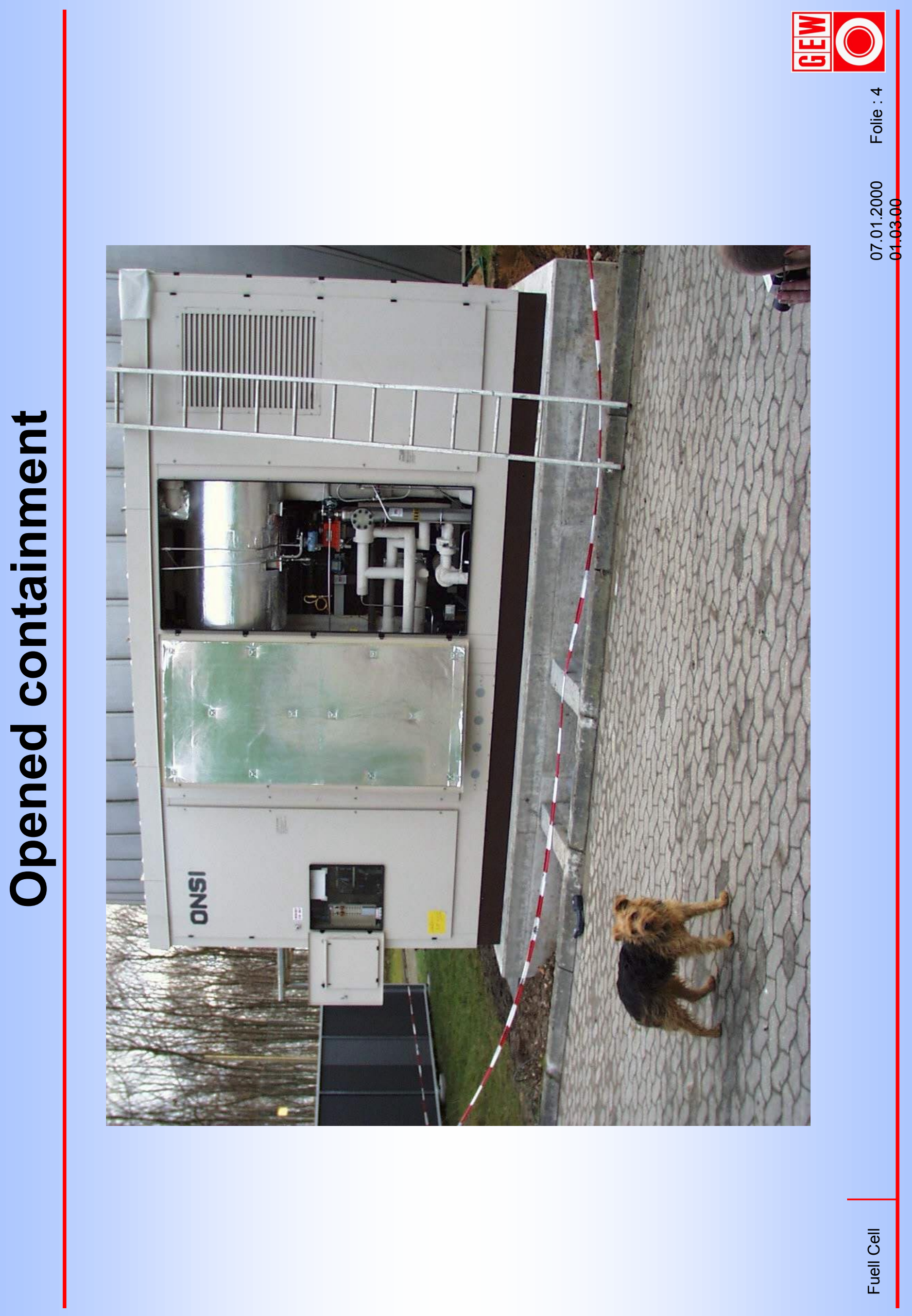




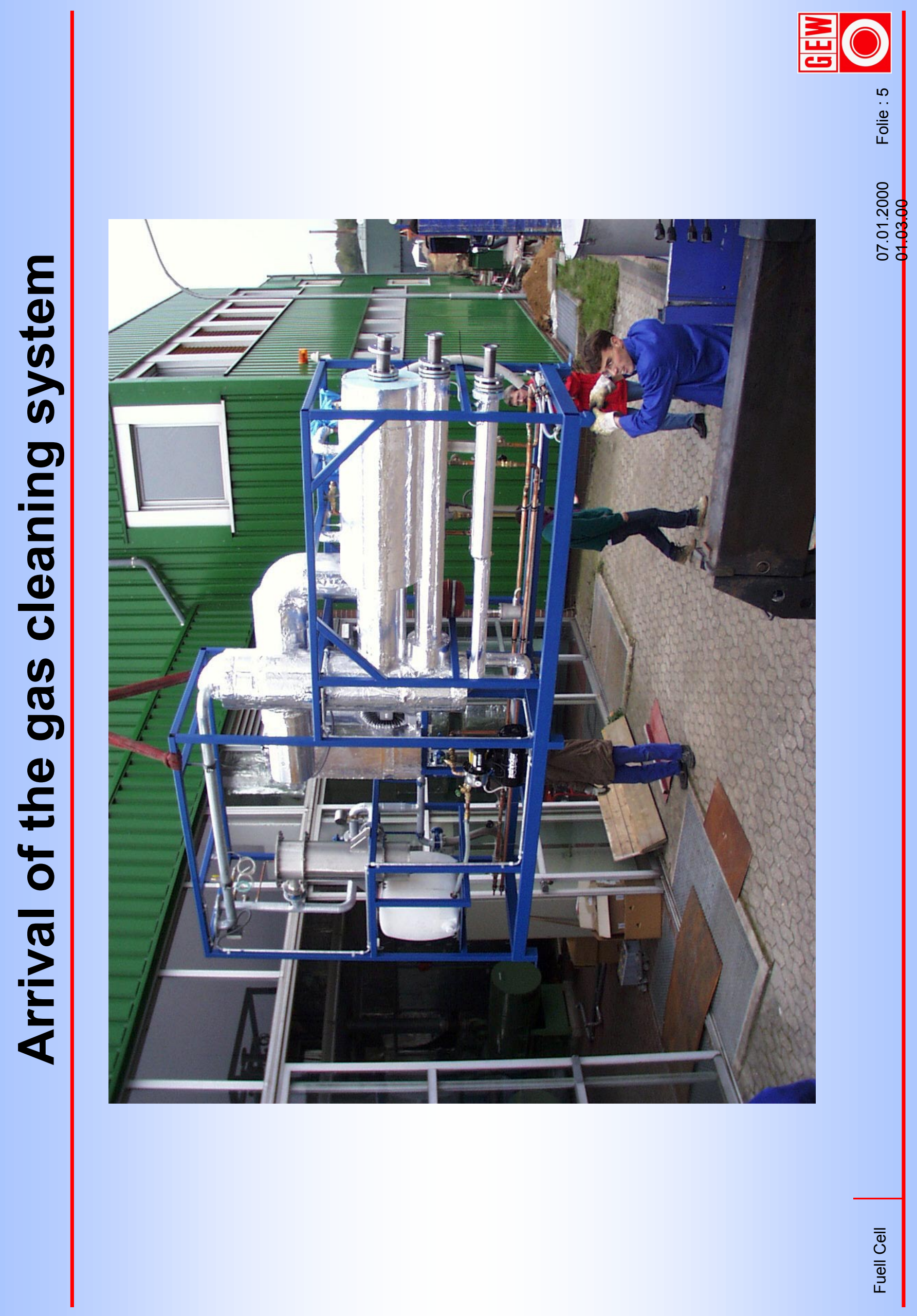




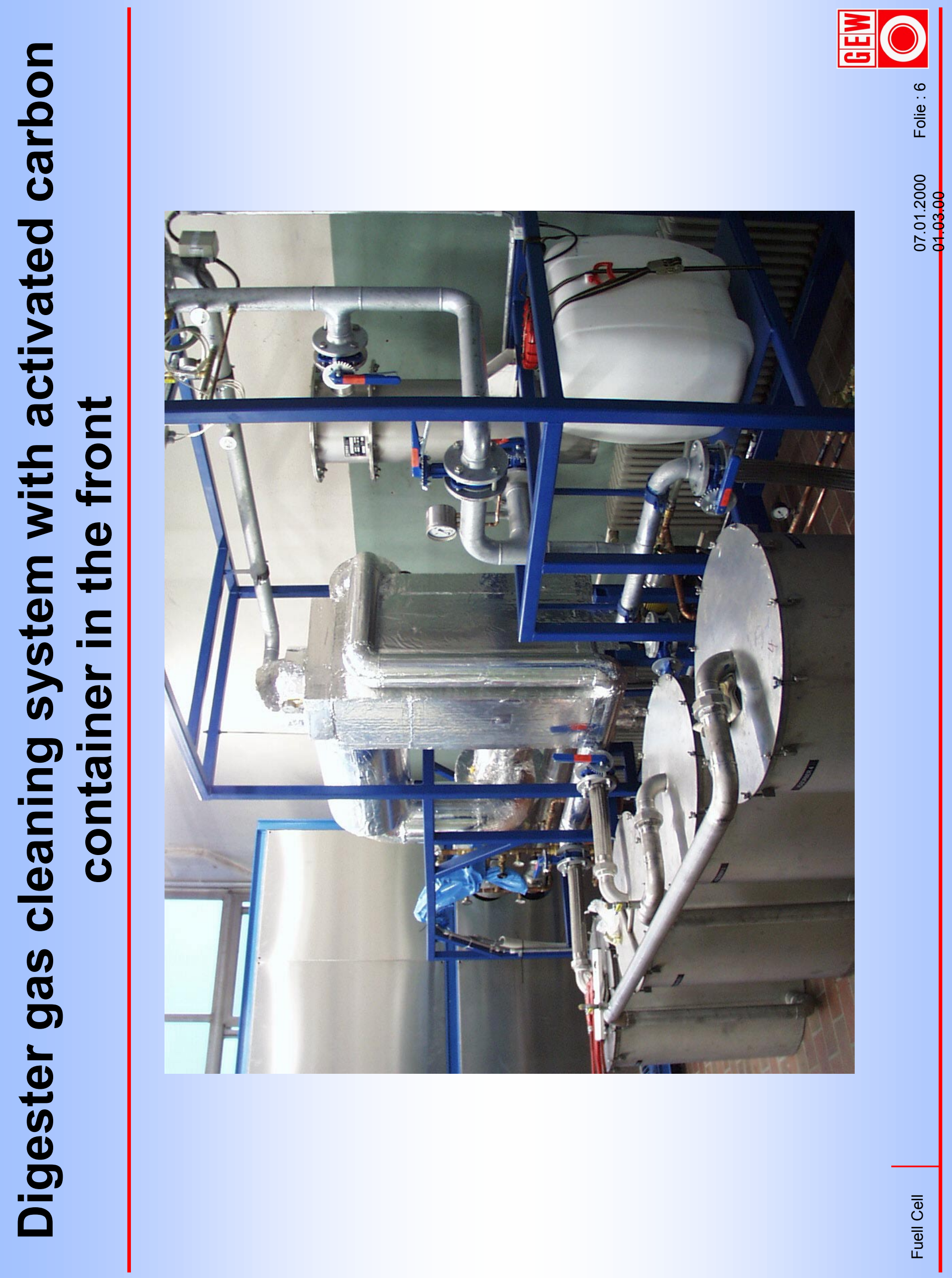




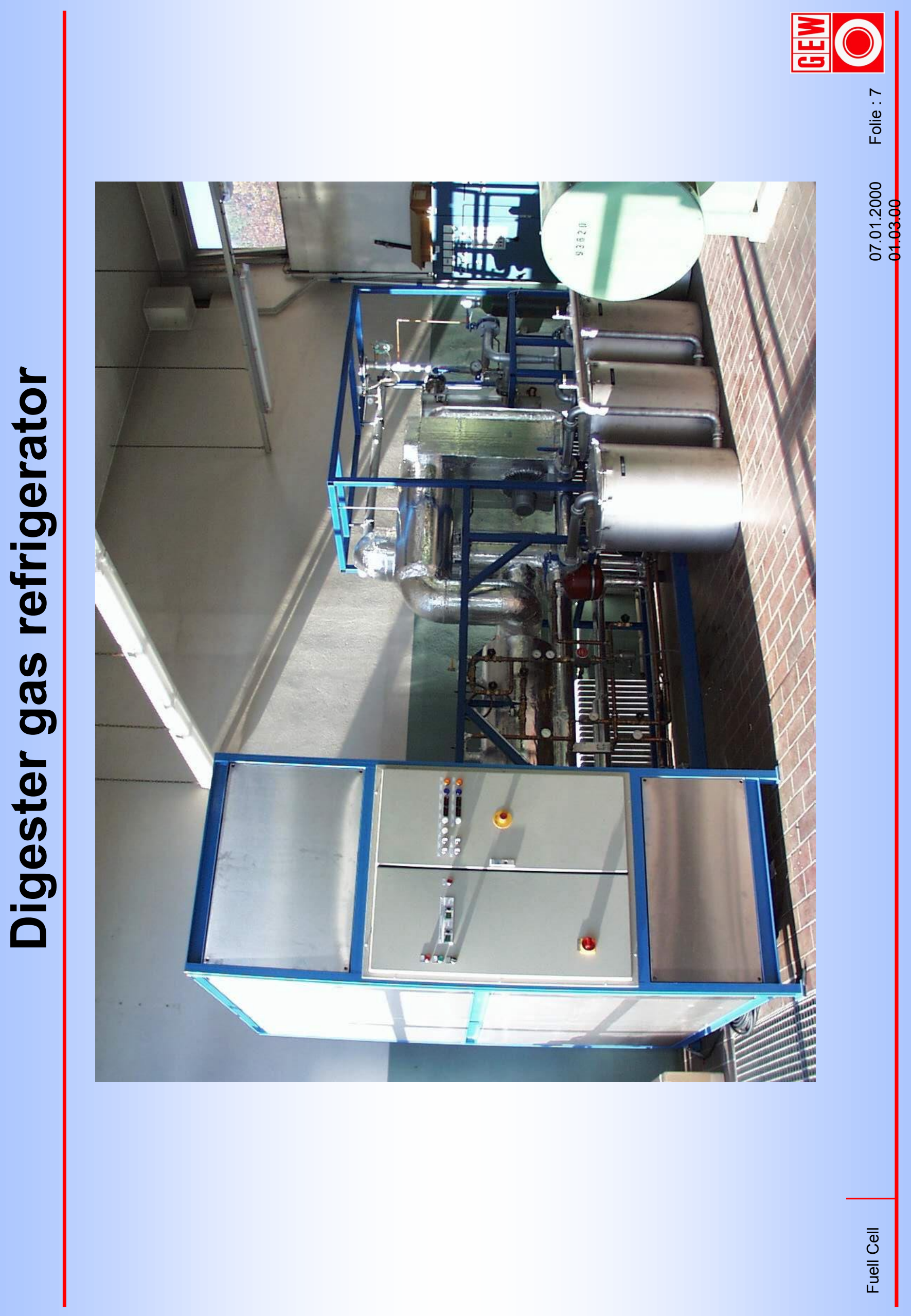



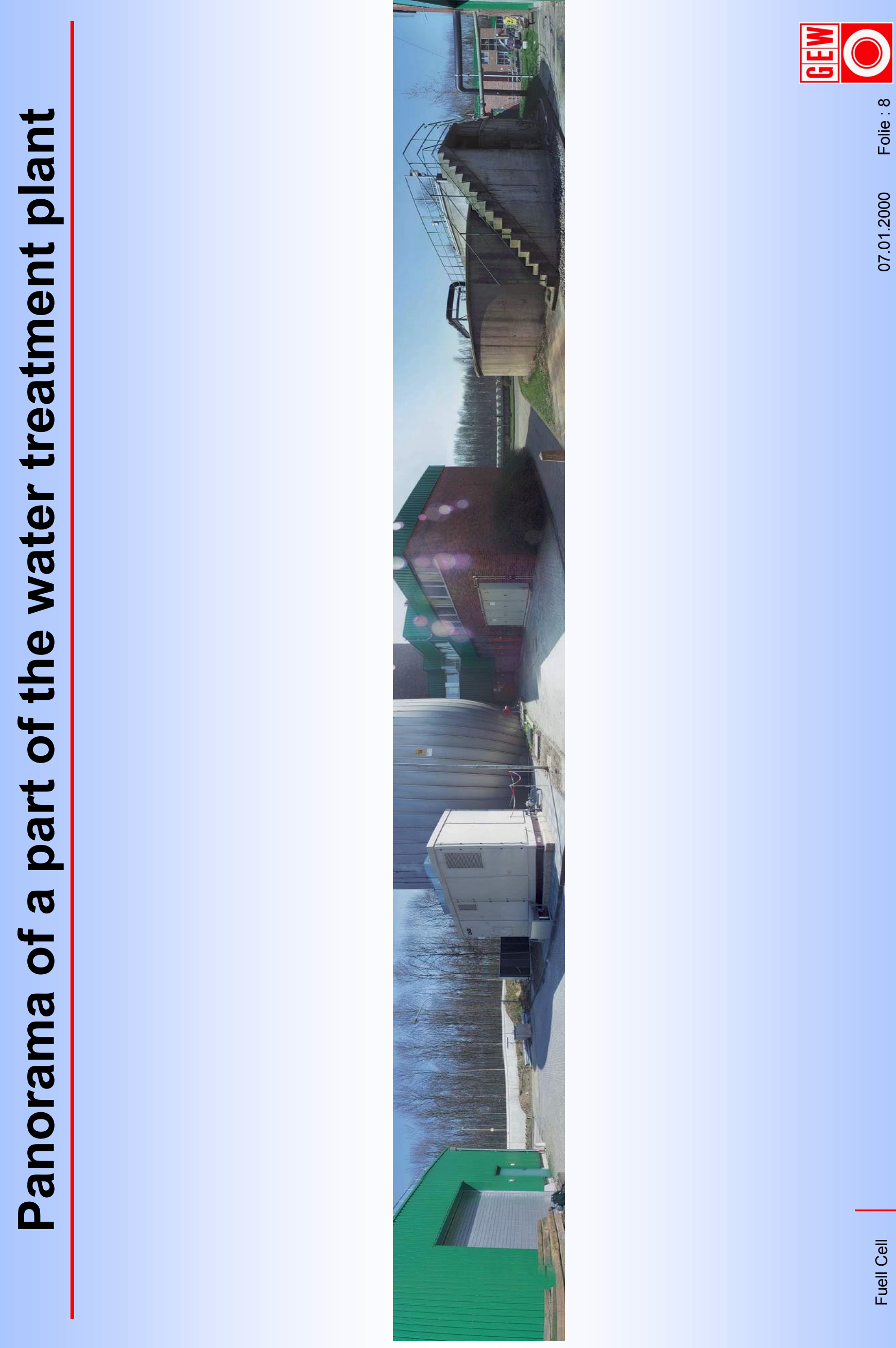

\begin{tabular}{l}
$\infty$ \\
\hdashline \\
$\frac{0}{0}$ \\
\end{tabular}

ํํㅇ

ㄷํㅇㅇ

$\overline{\overline{0}}$
$\overline{\overline{0}}$
$\overline{1}$ 